\title{
An annual assessment of air quality with the CALIOPE modeling system over Spain
}

\author{
J.M. Baldasano ${ }^{a, b}$, M.T. Pay ${ }^{a}$, O. Jorba ${ }^{a}$, M. Piot ${ }^{a}$, P. Jiménez-Guerrero ${ }^{c}$ \\ aEarth Sciences Department. Barcelona Supercomputing Center. Barcelona, Spain \\ ${ }^{b}$ Environmental Modeling Laboratory, Technical University of Catalonia, Barcelona, Spain \\ 'Department of Physics, University of Murcia, Murcia, Spain
}

\begin{abstract}
The CALIOPE project, funded by the Spanish Ministry of the Environment, aims at establishing an air quality forecasting system for Spain. With this goal, CALIOPE modeling system was developed and applied with high resolution (4 $\mathrm{km} \times 4 \mathrm{~km}, 1 \mathrm{hr}$ ) using the HERMES emission model (including emissions of resuspended particles from paved roads) specifically built up for Spain. The present study provides an evaluation and an assessment of that air quality modeling system, namely WRF-ARW/HERMES/CMAQ/BSC-DREAM8b for a full year simulation in 2004 over Spain. The evaluation focused on the capability of the model to reproduce the temporal and spatial distribution of gas phase species $\left(\mathrm{NO}_{2}, \mathrm{O}_{3}\right.$, and $\left.\mathrm{SO}_{2}\right)$ and particulate matter (PM10) against ground-based measurements from the Spanish air quality monitoring network. The evaluation of the modeling results on an hourly basis showed a strong dependency of the performance of the model on the type of zone (urban, suburban and rural) and the dominant emission sources (traffic, industrial, and background). The $\mathrm{O}_{3}$ chemistry is best represented in summer, when mean hourly variability and high peaks are generally well reproduced. The mean normalized error and bias meet the recommendations proposed by the United States Environmental Protection Agency (US-EPA) and the European regulations. Modeled $\mathrm{O}_{3}$ shows higher performance for urban than for rural stations, especially at traffic stations in large cities, since stations influenced by traffic emissions (i.e. high $\mathrm{NO}$ x emissions) are better characterized with a more pronounced daily variability. $\mathrm{NO}_{x} / \mathrm{O}_{3}$ chemistry is better represented under non-limited-NO 2 regimes. $\mathrm{SO}_{2}$ is mainly produced from isolated point sources (power generation and transformation industries) which generate large plumes of high $\mathrm{SO}_{2}$ concentration affecting the air quality on a local to national scale where the meteorological pattern is crucial. The contribution of mineral dust from the Sahara desert through the BSC-DREAM8b model helps to satisfactorily reproduce episodic high PM10 concentration peaks at background stations. The model assessment indicates that one of the main air quality-related problems in Spain is the high level of $\mathrm{O}_{3}$. A quarter of the Iberian Peninsula presents more than 30 days exceeding the value $120 \mu \mathrm{g} \mathrm{m}^{-3}$ for the maximum 8-hr $\mathrm{O}_{3}$ concentration as a consequence of the transport of $\mathrm{O}_{3}$ precursors downwind the Madrid and Barcelona metropolitan areas, and industrial areas and cities in the Mediterranean coast.
\end{abstract}

Corresponding author at: Earth Science Department, Barcelona Supercomputing Center-Centro Nacional de Supercomputación (BSC-CNS), 
Jordi Girona 29, Edificio Nexus II, 08034 Barcelona, Spain. Tel.: +34 9341377 19; Fax: +34 934137721 .

Email address: jose.baldasano@bsc.es (J.M. Baldasano)

Keywords: Model evaluation, Air quality, Spain, High resolution, $\mathrm{O}_{3}$ Exceedances.

\section{Introduction}

In Europe, human health issues caused by degraded air quality have been extensively studied (Brunekreef and Holgate, 2002; Gryparis et al., 2004; Pénard-Morand et al., 2005), and have motivated the increase of monitoring infrastructures and modeling capabilities. In this sense, the European Commission (EC) and the U.S. Environmental Protection Agency (US-EPA), among others, have shown a great interest in air pollution transport and dynamics. Both entities have set ambient air quality standards for acceptable levels of $\mathrm{O}_{3}$ (US-EPA, 1991; European Commission, 2008), $\mathrm{NO}_{2}, \mathrm{SO}_{2}, \mathrm{PM} 2.5$ and PM10 in ambient air. According to the European regulations (European Commission, 2008), local to regional air quality models are useful tool to assess and understand the dynamics of air pollutants, to forecast the air quality, and to develop emission abatement plans and alert the population when health-related issues occur.

Air pollution limit values and allowed numbers of exceedances established by the European Commission (2008) are still exceeded in the atmospheric boundary layer in Europe and, particularly, in Spain (de Leeuw and Vixseboxse, 2010). Despite improvements due to European legislations, particulate matter and ground-level ozone remain important pollutants affecting human health (EEA, 2009a,b, 2010). The impact of these European policies on the pollutant levels was assessed by the Clean Air For Europe (CAFE) programme (Amann et al., 2004; Cuvelier et al., 2007).

The CALIOPE project, funded by the Spanish Ministry of the Environment, (Ministerio de Medio Ambiente y Medio Rural y Marino), aims at establishing an air quality forecasting system for Spain (Baldasano et al., 2008a). CALIOPE (Fig. 1) encompasses a high-resolution air quality forecasting system, namely WRFARW/HERMES-EMEP/CMAQ/BSC-DREAM8b, being applied to Europe as a mother domain: $12 \mathrm{~km} \times 12 \mathrm{~km}, 1 \mathrm{hr}$ (Pay et al., 2010) as well as to Spain as the nested domain: $4 \mathrm{~km} \times 4 \mathrm{~km}, 1 \mathrm{hr}$. Such high resolution of the modeling system is made possible by its implementation on the MareNostrum supercomputer hosted by the Barcelona Supercomputing Center-Centro Nacional de Supercomputación (BSC-CNS). Four Spanish research institutes compose the CALIOPE project: the BSC-CNS, the "Centro de Investigaciones Energéticas, Medioambientales y Tecnológicas" (CIEMAT), the Institute of Earth Sciences Jaume Almera of the "Centro Superior de Investigaciones Científicas "(IJACSIC) and the "Centro de Estudios Ambientales del Mediterráneo" (CEAM). In this project both experimental and operational modeling aspects are conducted by the BSC-CNS and CIEMAT while IJA-CSIC and CEAM lead the data monitoring part for the evaluation processes. Current forecasts are available through http://www.bsc.es/caliope. 
To date, a total of 23 model systems routinely simulate the air quality over Europe, with seven systems also operated in the forecasting mode (Menut and Bessagnet, 2010). Due to the episodic nature of dust outbreaks, the representation of these events cannot be well simulated with solely the information of aerosol boundary conditions (Jiménez-Guerrero et al., 2008a; Menut and Bessagnet, 2010). Vautard et al. (2005a) showed that simulated aerosol loadings, using the current knowledge on aerosol mechanisms, may be underestimated by up to $30-50 \%$ if only anthropogenic sources are taken into account. Among the seven operational systems CALIOPE is the unique system including the contribution of Saharan dust on an hourly basis. In addition, CALIOPE includes the High-elective Resolution Modelling Emission System (HERMES, see Baldasano et al., 2008b) specifically applied with high-resolution over Spain.

Several studies investigated air quality concerns over selected areas in Spain (San José et al., 1999; Jiménez-Guerrero et al., 2008b; Vivanco et al., 2008) or over the entire Peninsula (Baldasano et al., 2008a; Jiménez-Guerrero et al., 2008a; Vivanco et al., 2009). Most models ran with horizontal cell resolution of $18 \mathrm{~km} \times 18 \mathrm{~km}$ or coarser for domains covering the Spanish territory. CALIOPE now uses a $4 \mathrm{~km} \times 4 \mathrm{~km}$ cell resolution to simulate the lberian Peninsula domain. Such high resolution is a key factor to accurately simulate air pollution issues, especially over complex topography (Jiménez et al., 2006) and meteorology patterns (Baldasano et al., 1994; Millán et al., 2002a) in southern Europe.

The present paper provides a quantitative performance assessment of the CALIOPE modeling system to simulate the air quality in Spain (gas phase and particulate matter). As the HERMES emission database was compiled for the year 2004 the evaluation was carried out over this year. The performance of the modeling system is evaluated by means of comparisons with ground-based observations from the Spanish network here in after referred to as "RedESP" (source: CEAM, see Fig.2). The model dynamics are evaluated together with the corresponding statistics. The results are then compared to model performance goals and criteria. This study intends to warrant the suitability of CALIOPE over Spain for air quality concerns and forecast.

Section 2 describes the different models used in the CALIOPE system, the observational dataset and the statistical parameters calculated. Section 3 analyses the system results against available observations for the year 2004 and the modeled annual distribution of $\mathrm{NO}_{2}, \mathrm{O}_{3}, \mathrm{SO}_{2}$ and $\mathrm{PM} 10$. A discussion about the exceedances of $\mathrm{O}_{3}$ during summertime is shown in Section 4. The conclusions are presented in Section 5.

\section{Methods}

\subsection{System Description}

The CALIOPE air quality system is a state-of-the-art modeling framework currently under further development. As shown in Fig. 1, CALIOPE is a complex system that integrates a meteorological model (WRF-ARW), an emission processing model (HERMES), a mineral dust atmospheric model (BSCDREAM8b), and a chemical transport model (CMAQ) together in an air quality forecasting system.

The Advanced Research Weather Research and Forecasting (WRF-ARW) 
model v3.0.1.1 (Michalakes et al., 2004; Skamarock and Klemp, 2008) provides the meteorology to the chemical transport model. For the Spanish domain WRFARW is configured with a grid of $397 \times 397$ points corresponding to a $4 \mathrm{~km} \times 4$ $\mathrm{km}$ horizontal resolution and $38 \sigma$ vertical levels with 11 characterizing the planetary boundary layer (PBL). The model top is defined at $50 \mathrm{hPa}$ to resolve the troposphere-stratosphere exchanges properly.

The Models-3 Community Multiscale Air Quality Modeling System (Models3/CMAQ, Byun and Ching, 1999; Binkowski, 1999; Byun and Schere, 2006), v4.5 is used to study the behavior of air pollutants from regional to local scales, due to its generalized coordinate system and its advanced nesting grid capability. According to the work by Jiménez et al. (2003) the photochemical mechanism used in this study is the Carbon Bond IV mechanism (CBM-IV, Gery et al., 1989). It includes gas, aerosol and heterogeneous chemistry. The production of sea salt aerosol (SSA) is implemented as a function of wind speed and relative humidity (Gong, 2003; Zhang et al., 2005) through the AERO4 aerosol module. This module comprises the following aerosol components: nitrate, sulfate, ammonium, elemental and organic carbon, soil, sodium, and chlorine. Unspecified anthropogenic aerosols and aerosol water are additionally kept as separate components. Aerosols are represented by a trimodal aerosol distribution (Aitken, accumulation and coarse mode) using the ISORROPIA thermodynamic equilibrium model (Nenes et al., 1998), each of them assumed to have a lognormal distribution (Binkowski and Roselle, 2003). Secondary inorganic aerosols (SIA) are generated by nucleation processes from their precursors to form nitrate ammonium and sulfate aerosols. Secondary organic aerosol (SOA) can be formed from aromatics (anthropogenic organic aerosols) and terpenes (biogenic organic aerosols, Schell et al., 2001). Aerosol deposition is treated by a second-generation deposition velocity scheme (Binkowski and Shankar, 1995; Venkatram and Pleim, 1999). For a more complete description of the processes implemented in CMAQ see Byun and Schere (2006).

The CMAQ horizontal grid resolution corresponds to that of WRF. Its vertical structure was obtained by a collapse from the $38 \mathrm{WRF}$ layers to a total of 15 layers steadily increasing from the surface up to $50 \mathrm{hPa}$ with a stronger density within the PBL.

In order to provide adequate boundary and initial conditions to the IP domain the CALIOPE model system was initially run on a regional scale $(12 \mathrm{~km} \times 12 \mathrm{~km}$ in space and 1 hour in time) to model the European domain (mother domain). Chemical boundary conditions for this domain were provided by the global climate chemistry model LMDz-INCA2 (Hauglustaine et al., 2004; Folberth et al., 2006). A detailed evaluation of the European simulation was recently presented in the companion paper by Pay et al. (2010). A one-way nesting was then performed to retrieve the meteorological and chemical conditions for the IP domain (see Fig. 1).

As highlighted by Lam and $\mathrm{Fu}$ (2009) stratospheric amounts of $\mathrm{O}_{3}$ interpolated from global chemical models and provided to the chemical lateral profiles may cause problems since CMAQ does not include a cross-tropopause exchange mechanism. Following their suggestion the stratospheric contribution of $\mathrm{O}_{3}$ from the mother domain was suppressed from the chemical boundary conditions to avoid inconsistent intrusions of stratospheric $\mathrm{O}_{3}$ down to the surface.

The HERMES model (Baldasano et al., 2008b) uses information and state-of- 
the-art methodologies for emission estimations. It calculates emissions by sector-specific sources or by individual installations and stacks. Raw emission data are processed by HERMES in order to provide a comprehensive description of the emissions to the air quality model. Emissions used for Spain are derived from the aggregation in space from $1 \mathrm{~km} \times 1 \mathrm{~km}$ dataset to $4 \mathrm{~km} \times 4 \mathrm{~km}$. HERMES was recently updated with the following: Inclusion of agriculture and livestock emissions (SNAP10 sector, see Baldasano et al., 2008b), correction of emission factors of isoprene in winter, improvement in the spatial distribution of biogenic emission and population density via the use of the Corine Land Cover information at a 250 m-resolution, introduction of emissions from the road traffic sector in small cities (SNAP07 sector). In addition, since a decade, emissions of resuspensed particles from paved road have received an increasing attention. Field measurements showed elevated levels of PM10 in the vicinity of roads (Lenschow et al., 2001). In Spain field measurements showed that resuspended particles from paved roads had a considerable impact on urban air pollution (Querol et al., 2004b). More recently, the resuspendable amount of particles was experimentally evaluated in the Barcelona area in Spain (Amato et al., 2009a,b; 2010). First model attempts to quantify particle emissions resulting from abrasion of vehicle components and road surface were presented by Rauterberg-Wulff (2000); LUA (2000); Venkatram (2000) following a preliminary formulation by US-EPA (1997). In the present work, HERMES model quantifies particle emissions resulting from abrasion of vehicle components and road surface is based on emission factor calculated by the European study developed by Düring et al. (2002).

The Dust REgional Atmospheric Model (BSC-DREAM8b) was designed to simulate and predict the atmospheric cycle of mineral dust (Nickovic et al., 2001; Pérez et al., 2006a,b). The domain considered in this study comprises northern Africa, the Mediterranean basin and Europe. BSC-DREAM8b is fully embedded within the NCEP/Eta meteorological driver (Janjic, 1994). It simulates the longrange transport of mineral dust at a $0.3^{\circ} \times 0.3^{\circ}$ resolution using 24 vertical layers extending up to $15 \mathrm{~km}$ in altitude on an hourly basis. The aerosol description contains 8 bins to allow a fine description of dust aerosols. Dust-radiation interactions are calculated online. An offline coupling is applied to the calculated concentrations of particulate matter from CMAQ (Jiménez-Guerrero et al., 2008).

The simulation consists of 366 daily runs constituting the year 2004. The first 12 hours of each daily meteorological runs are treated as cold start, and the next 23 hours are provided to the chemical transport model via the MeteorologyChemistry Interface Process from CMAQ (MCIP).

\subsection{Air Quality Network}

In order to evaluate the performances of the CALIOPE system at ground level over Spain, the hourly data from RedESP Spanish network of air quality monitoring stations were selected. The RedESP network comprises a relatively dense geographical coverage of the Spanish territory. The RedESP observational data provided by CEAM were subject to a preliminary quality control to exclude erroneous values. Then, all stations with a temporal coverage below $85 \%$ of the entire year 2004 were filtered out. The RedESP stations are characterized the type of zone (urban, suburban and rural) and the dominant emission source (traffic, industrial, and background) based on the proposition by 
Garber et al. (2002). Characteristics, location and measured pollutants of the RedESP stations are presented in Tab. 1 and Fig. 2. In summary, a total of 68 measuring stations were used for $\mathrm{NO}_{2}, 45$ for $\mathrm{SO}_{2}, 82$ for $\mathrm{O}_{3}$, and 44 for PM10, respectively.

\subsection{Statistical Indicators}

A variety of statistical parameters may be used to quantify how well CALIOPE system fits the observation (Denby et al., 2010). In particular, specific metrics were proposed depending on the pollutants (US-EPA, 1984, 1991; Cox and Tikvart, 1990; Weil et al., 1992; Chang and Hanna, 2004; Boylan and Russell, 2006).

Common statistical metrics used by the modeling community include the mean observed and modeled observed, the correlation coefficient ( $r$ ), the root mean square error (RMSE) and the mean bias (MB). Additionally, the mean normalized bias and gross errors, MNBE and MNGE respectively, considering all modeled/observed pairs of values are also useful parameters. For particulate matter, Boylan and Russell (2006) rather suggested the consideration of the Mean Fractional Bias (MFB) and the Mean Fractional Error (MFE) parameters since they are symmetric metrics, bounding the maximum bias and error.

The US-EPA suggested several performance criteria for simulated $\mathrm{O}_{3}$, such as MNBE $\leq \pm 15 \%$ and MNGE $\leq 35 \%$ (US-EPA, 1991, 2007) whereas the EC proposes a modeling quality objective given as a relative uncertainty (\%): $50 \%$ and $30 \%$ for $\mathrm{PM} 10 / \mathrm{PM}_{2} 5 / \mathrm{O}_{3}$ annual average and $\mathrm{NO}_{2} / \mathrm{SO}_{2}$ annual average, respectively (European Commission, 2008). However, the interpretation of the term model uncertainty remains unclear (Denby et al., 2010). Therefore, the latter criteria will not be further commented in this study. For particulate matter, Boylan and Russell (2006) proposed that the model performance criterion would be met when both MFE $\leq 75 \%$ and MFB $\leq \pm 60 \%$, respectively, and the model performance goal would be met when MFE and MFB are less than or equal to $50 \%$ and $\pm 30 \%$, respectively.

The annual mean model-to-data statistics RMSE, correlation coefficient, MNBE, MNGE, MFB and MFE were selected for the present study. According to the recommendations of the US-EPA a cut-off value of $80 \mathrm{\mu g} \mathrm{m}^{-3}$ was applied to O3 statistics before compilation (US-EPA, 1991; Russell and Dennis, 2000). However, correlation coefficients for $\mathrm{O}_{3}$ are calculated without cut-off value in order to test the capability of the model to reproduce the variation of $\mathrm{O}_{3}$ concentrations.

\section{Results and discussions}

First, this section shows a model evaluation through statistical and dynamical performances. Furthermore, a general description of the annual mean distribution of each pollutant is provided to determine each pattern throughout Spain. Note that statistics are calculated for hourly averages of $\mathrm{NO}_{2}, \mathrm{O}_{3}, \mathrm{SO}_{2}$, and PM10. In the case of $\mathrm{O}_{3}$, the daily peak of hourly $\mathrm{O}_{3}$ is also computed as it is one of the most important parameters to be considered. It is important to remark that neither correction factors nor any adjusting model parameterization were applied to the model output or the original model codes. 


\subsection{Nitrogen Dioxide}

The $\mathrm{NO}_{2}$ measurement dataset comprises a relatively equal distribution of station types with 21 urban, 22 suburban and 25 rural stations, respectively. Fig. 3a represents the measured (marked black line) and modeled (red line) time series of the hourly mean $\mathrm{NO}_{2}$ at the 68 measuring stations. The general modeled dynamics is well captured with a clear signal of the main winter pollution events. However, mean levels of $\mathrm{NO}_{2}$ are persistently underestimated (MB $=-12.3 \mu \mathrm{g} \mathrm{m}^{-3}$, not shown).

The statistics compiled in Table 2 show highest mean RMSE values at urban stations $\left(33.6 \mathrm{\mu g} \mathrm{m}^{-3}\right)$ and lowest values for rural stations $\left(7.6 \mathrm{\mu g} \mathrm{m}^{-3}\right)$. This characteristic is not surprising, since urban stations are more likely to be influenced by high, very local emission sources from urban activities which remain difficult to be captured by models. Both MFB and MFE metrics show relatively constant values among the station types, suggesting that the model error for $\mathrm{NO}_{2}$ is proportional to the normalized observed value. Overall, however, the modeled daily and monthly variations of $\mathrm{NO}_{2}$ are in good agreement with observations, although a reduced magnitude of the variability is noted. Among the best model behaviours reported, the majority corresponds to either rural stations influenced by background emissions (mean RMSE $=6.3 \mu \mathrm{g} \mathrm{m} \mathrm{m}^{-3}$ compared to $7.6 \mathrm{\mu g} \mathrm{m}^{-3}$ for all rural stations) or urban stations located in very large (and well characterized) cities such as Madrid or Barcelona (MFB $=-46.4 \%$ compared to $-97.7 \%$ for all urban stations). In general, measurements at suburban or urban stations from small- to medium-size cities were simulated with less accuracy. From the 68 stations measuring $\mathrm{NO}_{2}, 13$ (19\%) were not represented correctly by the model. Most of these stations are placed in small cities and are often located in the vicinity of isolated roads or highways (e.g., Acueducto, Estación, Roger Flor, Verge, Table 1). We attribute such behavior to the incomplete characterization of emissions from small cities and to the influence of the model resolution on sub-grid emission sources. The latter, also known as sub-grid variability, is a well-known issue affecting the results of model-observation comparisons (e.g., Ching et al., 2006). Also, $\mathrm{NO}_{2}$ concentrations in background areas were found to be systematically underestimated. This trend is supported by the lack of biomass burning (Ortiz de Zárate et al., 2005), biogenic soil emissions (Slemr and Seiler, 1984) and natural $\mathrm{NO} x$ production such as lightnings which are currently not treated in the CALIOPE model system (Smith and Mueller, 2010). In addition, biogenic emissions from vegetated and agricultural areas (SNAP10 sector) in HERMES may need further revision.

Fig. 4a displays the annual average modeled levels of $\mathrm{NO}_{2}$ over Spain. High concentrations of $\mathrm{NO}_{2}$ within the PBL are directly related to anthropogenic $\mathrm{NO}_{x}$ emission. Baldasano et al. (2008a) estimated that the largest $\mathrm{NO}_{\mathrm{x}}$ emission sources come from combustion in energy and transformation industries $(41 \%$ of $\mathrm{NO}_{x}$ total emission) followed by road transport ( $37 \%$ of $\mathrm{NO}_{x}$ total emission).

The urban plumes from Madrid and Barcelona metropolitan areas reach the highest $\mathrm{NO}_{2}$ concentrations $\left(\sim 25-40 \mu \mathrm{g} \mathrm{m}^{-3}\right)$. In both regions, on-road traffic constitutes the main source of primary pollutants in the region (Gonçalves et al., 2009). In Madrid the $\mathrm{NO}_{2}$ dispersion follows a south-western direction conditioned by the barrier of Central System (located in the north-western area, $2500 \mathrm{~m}$ height) and the canalization of Tajo valley (located in the southern part). 
The urban plume reaches the highest concentration at the urban nuclei $(\sim 40 \mu \mathrm{g}$ $\mathrm{m}^{-3}$ ), moving towards Toledo (south) and reaching Guadalajara (east) in a lesser extent. A different $\mathrm{NO}_{2}$ pattern is observed in Barcelona area. The $\mathrm{NO}_{2}$ dispersion presents a perpendicular flow to the coast dominated by the northwestern winds. The very complex coastal terrain induces mesoscale phenomena which control the superficial wind flows. Sea-breezes and mountain valley winds contribute to the accumulation and recirculation of air masses. The littoral mountain chain (1000 - 1500m height) acts as a barrier, recirculating $\mathrm{NO}_{2}$ towards the Mediterranean Sea, and also river valleys channel the $\mathrm{NO}_{2}$ flow.

The densely industrialized area of Tarragona and Castellón and the urban area of Valencia, they all located along the Mediterranean coast, present significant levels of $\mathrm{NO}_{2}$ affected also by mesoscale phenomena dominated by sea-breezes which determinate $\mathrm{NO}_{2}$ flow perpendicular to the coast. In the northern Spain, the urban and industrialized area of Bilbao present significant $\mathrm{NO}_{2}$ levels $\left(\sim 25 \mathrm{\mu g} \mathrm{m}^{-3}\right)$ dispersed along an estuary that runs almost $16 \mathrm{~km}$ from the center of the city to the sea and is aligned in an SE-NW direction.

In the north-eastern Spain the $\mathrm{NO}_{2}$ contribution from power plants emission is bigger than the urban contribution, where $\mathrm{NO}_{2}$ annual mean concentration

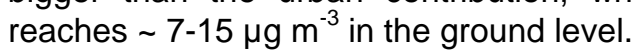

Due to the high disaggregation and the specifically detailed emissions implemented in the HERMES model, the impact of principal highways is noticeable, (e.g., Madrid-Sevilla, Barcelona-Bilbao, the A-7 Mediterranean highway) where annual mean values range from 3 to $7 \mu \mathrm{g} \mathrm{m}^{-3}$. Background regions, unaffected by emissions rather have concentrations below $3 \mu \mathrm{g} \mathrm{m}^{-3}$.

The major shipping route originating from the northern Atlantic and the British Channel, passing along Portugal coast, through the Strait of Gibraltar heading and toward northern Africa and the Suez Canal is shown to have a notable impact on $\mathrm{NO}_{2}$ levels. Concentrations of $\mathrm{NO}_{2}$ range from $\sim 5 \mu \mathrm{g} \mathrm{m}^{-3}$, near the coastlines of Portugal and Gulf of Cadiz, to $\sim 12 \mu \mathrm{g} \mathrm{m}^{-3}$, over the Alboran Sea. This difference is accentuated by the distinct Atlantic-Mediterranean regimes of Spain. Meanwhile in the Mediterranean dynamics in summer is characterized by re-circulation and accumulation of pollutant, a strong dynamically compensated anticyclonic inversion dominates the Spanish Atlantic coast and the west of Portugal (Millán et al., 1997). In the Strait of Gibraltar high $\mathrm{NO}_{2}$ concentration are estimated $\left(\sim 30 \mathrm{\mu g} \mathrm{m}^{-3}\right)$ where two contributions are combined, the maritime traffic and the industrial processes and electric generation developed in the Algeciras area. The complex topography of the Strait induces the $\mathrm{NO}_{2}$ dispersion aligned in a west to east direction, with generalized strong east wind (Millán et al., 2002b).

\subsection{Ozone}

This study comprises a total of 82 RedESP stations measuring $\mathrm{O}_{3}$ throughout Spain for the year 2004. 24 stations are located in urban areas, 25 in suburban zones and 33 in rural areas, respectively. Modeled and measured time series and scatter plot are presented in Fig. 5 with the corresponding statistics in Tab. 3. Time series for $\mathrm{O}_{3}$ daily peak (Fig. $5 \mathrm{a}$ ) show that the $\mathrm{O}_{3}$ chemistry is best represented in summer. In the high photolytical season, the mean variability and high peaks are generally well reproduced. The modeled variability in winter months is characterized by difficulties to capture the mean trend due to 
inaccurate description of cross-tropopause exchanges in CMAQ (Pay et al., 2010). However, the discussion of the evaluation will mainly focus on the high $\mathrm{O}_{3}$ season (from April to September).

Statistical parameters in hourly basis consistently show better results for stations located in urban areas, followed by suburban and rural areas. The correlation coefficient at all urban stations reaches a maximum of 0.60 with values per station ranging from 0.35 to 0.75 . Most of stations display values of MNGE and MNBE lying within the acceptable range defined by the USEPA (Fig. $6 c$ and $d$, respectively) with low values for MFB and MFE metrics. Table 3 and Fig. 6a also displays the statistics for $\mathrm{O}_{3}$ daily peaks. Rural areas are characterized by a general underestimation of $\mathrm{O}_{3}$ daily peaks $\left(\sim 7 \mu \mathrm{g} \mathrm{m}^{-3}\right)$ while peak concentrations at urban stations are rather overestimated $\left(8.4 \mu \mathrm{g} \mathrm{m}^{-3}\right)$ (Fig. $6 b)$. High correlations are noted for each type of station. In summary the model system used in this study performs well with respect to the simulation of high $\mathrm{O}_{3}$ concentrations over Spain. However, an overestimation of nocturnal values is depicted with recurrent low daily variations due to uncertainties in the modeled nocturnal $\mathrm{NO} \times$ cycle, which is a common feature in chemical transport models.

Stations influenced by traffic emissions (i.e. high NOx emissions) are better characterized with a more pronounced daily $\mathrm{O}_{3}$ variability. To complement such finding, Fig. 7, representing the $\mathrm{O}_{3}$ model-to-observation bias as a function of the modeled $\mathrm{NO}_{2}$ concentrations for all the 68 stations measuring both $\mathrm{NO}_{2}$ and $\mathrm{O}_{3}$, is proposed in order to evaluate the performances of the model with respect to the $\mathrm{NO} / \mathrm{O}_{3}$ chemistry.

While a deviation from the $\mathrm{O}_{3}$ bias is mainly constrained by the lateral chemical boundary conditions, the width of the plotted dataset is controlled by the chemical mechanism implemented in the model. This figure clearly shows that the highest uncertainties in the reproduction of $\mathrm{O}_{3}$ levels are related to $\mathrm{NO}_{2}-$ limited regime. Under this regime, corresponding to background conditions, the $\mathrm{O}_{3}$ bias is slightly shifted to the right, meaning that the modeled $\mathrm{O}_{3}$ tends to overestimate observed values, specifically during nighttime (also see mean observed and modeled values for rural stations in Tab. 3). As a contrary, the width of $\mathrm{O}_{3}$ model-to-observation biases decreases with increasing modeled $\mathrm{NO}_{2}$. Such behavior reflects the better representation of the $\mathrm{NO}_{x} / \mathrm{O}_{3}$ chemistry under non-limited-NO2 regimes, but it also shows that the chemistry under higher- $\mathrm{NO}_{2}$ regime has a reduced dependency to the lateral chemical conditions of the model (no shift on the X-axis). As an example, data from Sierra Norte (Rural Background, light grey triangles) and Recoletos (Urban Traffic, dark grey squares) are overlaid on the figure. The $\mathrm{O}_{3}$ bias at Sierra Norte displays a wide variability related to low modeled $\mathrm{NO}_{2}$ whereas the bias for Recoletos markedly diminishes with increasing modeled $\mathrm{NO}_{2}$. Such description confirms the higher performances of the model for urban stations than for rural stations. This behavior highlights the need to better characterize the emission inventory for background areas (see discussion in Sect. 3.1). The curve interpolating the average $\mathrm{O}_{3}$ bias in vertical also confirms the higher bias values under low $\mathrm{NO}_{2}$ regime (maximum bias $\mathrm{O}_{3} \sim 22 \mathrm{\mu g} \mathrm{m}^{-3}$ for $\left[\mathrm{NO}_{2}\right]$ model $=15 \mu \mathrm{g} \mathrm{m}^{-3}$ ), while it remains significantly lower for $\mathrm{NO}_{2}$ modeled concentration above $60 \mathrm{\mu g} \mathrm{m}^{-3}$.

The annual mean distribution of $\mathrm{O}_{3}$ over the IP is presented in Fig. 4b. Highest mean concentrations are located in the open Mediterranean Sea (up to $90 \mu \mathrm{g} \mathrm{m}^{-3}$ ) and the Spanish Mediterranean coast $\left(\sim 80 \mu \mathrm{g} \mathrm{m}^{-3}\right)$. Such concentrations are favoured by the prevailing intense photochemistry in the 
region (EEA, 2005; Vautard et al., 2005b), the local formation and transport (Lelieveld et al., 2002; Gerasopoulos et al., 2005; Cristofanelli and Bonasoni, 2009), the persistent subsidence over the region (Millán, 2002a) and the low $\mathrm{O}_{3}$ depletion over sea. The Spanish oceanic region in the north and north-western Spain, characterized by high frequency of precipitation presents lower $\mathrm{O}_{3}$ levels than the Spanish arid and mediterranean regions. The wet deposition of $\mathrm{O}_{3}$ is an important sink in the oceanic regions, meanwhile local generation and transport are the processes which contribute to $\mathrm{O}_{3}$ levels in arid and Mediterranean regions.

The Fig. 4b also highlights significant levels over the major Spanish mountain ranges such as the Pyrenean chain, the Baetic Cordillera (southeastern Spain) or the Sierra Norte (laying north of Madrid in a west-to-northeast direction), reflecting the $\mathrm{O}_{3}$ vertical gradient in the atmosphere.

$\mathrm{O}_{3}$ is found lowest $\left(\sim 50 \mu \mathrm{g} \mathrm{m}^{-3}\right)$ in either regions of low precursor emissions (northern and southern plateaus) or in areas affected by large NO-to-NO2 concentration ratios (e.g., zones of intense on-road and ship traffic). Reactions involving nitrogen oxides are wellknown key reactions controlling the amount of $\mathrm{O}_{3}$ in the troposphere (Fishman and Crutzen, 1978). In this chemical regime reactions between $\mathrm{NO}_{2}$ and $\mathrm{O}_{3}$ prevail, leading to low levels of $\mathrm{O}_{3}$. These areas comprise the major Spanish metropolitan cities (i.e., Madrid, Barcelona, Valencia, Sevilla), highways of high traffic flow (like NO2, see Sect. 3.1) and the major shipping routes in the Mediterranean Sea.

\subsection{Sulfur Dioxide}

From a total of 45 stations measuring $\mathrm{SO}_{2}, 13$ are located in urban areas, 14 in suburban and 18 in rural areas, respectively. In Spain, $\mathrm{SO}_{2}$ is mainly produced by power generating and transformation industries. Indeed, Linares and Romero (2000) reported that electricity generation contributes $66 \%$ to the total $\mathrm{SO}_{2}$ emitted in Spain. These very localized industries generate large plumes of high$\mathrm{SO}_{2}$ content affecting the air quality on a local to national scale. Modeling $\mathrm{SO}_{2}$ for air quality purposes is a complex issue, since the accuracy in the meteorological patterns is crucial for the determination of plume dynamics. Also, the variability on the sub-grid scale must be considered when comparing model results with measured data. The mean hourly $\mathrm{SO}_{2}$ variability and levels are very well captured by the modeling system (Fig. 3b). Episodic extreme values are underestimated in general, although the model is capable of reproducing the trend. Mean biases are low (from -3.1 for urban to $0.6 \mathrm{\mu g} \mathrm{m}^{-3}$ for suburban stations). Due to the frequently episodic character of high $\mathrm{SO}_{2}$ events and their dependency to meteorology correlation coefficients are rather low ( $r=0.14$ for urban/suburban stations; 0.28 for rural stations). Highest correlations were obtained for background stations $(r=0.34)$. MFB values show good performance comparing with the other primary pollutants $(-47.1 \%<$ MFB $<-23.8 \%)$ but MFE values highlight the need to further improve the modeled $\mathrm{SO}_{2}$ physico-chemistry. Among the 45 stations measuring $\mathrm{SO}_{2}$ in the Peninsula, the model-to-data comparison was distinctly unsatisfactory for three locations (7\% of the total). Two of these locations were found in the same grid cell as large power plants (Abanto and Grao). A third station ("Salamanca2" in the city of Salamanca) displays high $\mathrm{SO}_{2}$ measured concentrations which are strongly underestimated by the model. Such behavior may be explained by emission sources unaccounted by the 
model system or by the erroneous coordinates of the instrument.

In Spain, Baldasano at al. (2008a) reported that combustion in energy and transformation industries contributes $83 \%$ to the total $\mathrm{SO}_{2}$ emitted in Spain. In this framework, the $\mathrm{SO}_{2}$ is emitted mainly from large isolated point sources, instantaneously mixed in high layers in the atmosphere and transported and dispersed following the plume dynamic. The mean chemical distribution of $\mathrm{SO}_{2}$ over the IP, shown in Fig. 4c, is characterized by two major patterns. First, the Spanish territory is marked by various emission hot-spots often reaching air concentrations above $15 \mathrm{\mu g} \mathrm{m}^{-3}$. These localized sources originate mainly from power plants and refineries.

Northern Spain suffers substantial $\mathrm{SO}_{2}$ mean annual levels of up to $\sim 10 \mu \mathrm{g}$ $\mathrm{m}^{-3}$ due to the presence of geographically-close power plants and refineries in the area of Galicia, Ponferrada, Asturias and Bilbao. $\mathrm{SO}_{2}$ reaches maximum levels $\left(\sim 50 \mathrm{~g} \mathrm{~m}^{-3}\right)$ near the two refineries in Bilbao and La Coruña. The $\mathrm{SO}_{2}$ dispersion pattern in north-western Spain is significantly dominated by the northern and north-western winds that transport $\mathrm{SO}_{2}$ inland. Eastern Spain is mostly affected by a thermo-electrical power plant from Teruel (Aragón region), the pattern is dominated by the canalization of the Ebro valley towards the Mediterranean sea. The southern Spanish plateau displays high $\mathrm{SO}_{2}$ levels around Puertollano (Castilla-La Mancha region) due to the presence of a refinery and two power plants.

In the urban areas the $\mathrm{SO}_{2}$ dispersive pattern remains $\sim 6 \mu \mathrm{g} \mathrm{m}^{-3}$; in Madrid and Barcelona cities the levels of $\mathrm{SO}_{2}$ are sum of two contributions, the on-road traffic and the cogeneration plants. Minimum concentrations from unpolluted areas display mean values near $0.5-2 \mathrm{\mu g} \mathrm{m}^{-3}$.

The second pattern dissociated from this figure is the shipping route from the Atlantic, through the Strait of Gibraltar, toward the major Mediterranean harbours. Ship emissions are large contributors to the total $\mathrm{SO}_{x}$ concentrations along the main ship tracks due to fuel combustion of high sulfur content (Corbett and Fischbeck, 1997; Corbett and Koehler, 2003), although ship emission abatement strategies are under current application (Internacional Maritime Organization and Marine Environment Protection Committee, 2001). These emissions from maritime zones lead to coastal mean $\mathrm{SO}_{2}$ concentrations from 2 to $8 \mu \mathrm{g} \mathrm{m}^{-3}$ on annual average, with a maximum of $12-18 \mu \mathrm{g} \mathrm{m}^{-3}$ in the narrow Gibraltar regions with a dispersion pattern dominated by western winds. The $\mathrm{SO}_{2}$ contribution of shipping route in this area is combined with the contribution from one large refinery, industrial processes, and electric generation carried out in the Gibraltar bay.

\subsection{Particulate matter}

A total of 44 RedESP stations measured particulate matter concentrations over the IP and the Balearic Islands for the year 2004. 12 stations were located in rural areas, 17 in suburban and 15 in urban areas, respectively. Among these 44 stations, the model represented the PM concentrations fairly well at 17 locations (nearly $40 \%$ of the total). These locations were mostly background rural. In these areas mean concentrations are often low with episodic high concentration peaks. The implementation of the Sahara desert dust contribution from the BSC-DREAM8b model is responsible for the satisfactory representation of such concentration peaks. The evaluation of the modeling system highlighted 
less accurate modeled levels at suburban and urban locations mostly influenced by background emissions. Model-to-data comparisons in urbanized areas of industrial or traffic emissions showed lowest accuracy. We attribute such behavior to the defective characterization of emission sources in areas of intense human activity.

Fig. 3c clearly highlights two distinct aspects of the model in the representation of PM10 concentrations at all available stations. Modeled concentrations were persistently underestimated throughout the year 2004. This underestimation is a common feature of most of the current regional models (Pay et al., 2010). The mean annual bias amounts to $-21.8 \mu \mathrm{g} \mathrm{m}^{-3}$ with an annual RMSE value of $33.4 \mathrm{\mu g} \mathrm{m}^{-3}$. On the other hand, the general PM10 dynamics are well captured, with the major events correctly modeled and synchronized with measured amounts. The mean correlation for all stations amounts to 0.38 with higher correlations at rural stations $(r=0.43$, ranging from 0.28 to 0.58 per station). Due to the important underestimation of the model concentrations, MFB and MFE values are undoubtedly ranging above the criteria for acceptable model performances proposed by Boylan and Russell (2006).

Fig. $4 \mathrm{~d}$ shows the annual average pattern of natural and anthropogenic PM10 over the IP for 2004. Concentrations present a large variability across Spain depending on emission sources, climate and reactivity/stability of particulate species (see Querol et al., 2001, 2003, 2004a, 2008; Rodríguez et al., 2002; Viana et al., 2005). The spatial distribution of PM10 annual mean modelled levels shows that particle concentrations reach high values $\left(\sim 15 \mathrm{\mu g} \mathrm{m}^{-3}\right)$ in large cities like Madrid, Barcelona, Valencia, and Bilbao there is an important contribution of exhaust and non-exhaust emissions from road transport in urban areas.

Marine aerosols contribute nearly 3 and $5 \mu \mathrm{g} \mathrm{m}^{-3}$ to the annual mean PM10 concentration over the Mediterranean and Atlantic coasts, respectively (not shown). This difference in concentration reflects the higher wind speeds and fetch distances in the Atlantic than in the Mediterranean Basin leading to more transport of sea salt aerosols from the Atlantic open ocean to the coasts. The contribution of marine aerosols to PM10 annual concentrations over the open ocean ranges from 6 (Mediterranean Basin) to $9 \mu \mathrm{g} \mathrm{m}^{-3}$ (Atlantic) which is consistent with model data from Manders et al. (2010).

In the north, the industrial areas in Castellón dominated by ceramic industry, present high levels of PM10, dispersed along a perpendicular axis to the coast. Mediterranean coast presents PM10 dispersion pattern influenced sea-breezes combined with upslope winds to create recirculations along the coast and within the western Mediterranean basin. In summer the higher temperatures and solar radiation lead to the formation of secondary aerosols contributing to the levels of particulate matter. The Ebro valley acts by channelling particulate matter flow inland. Meanwhile in the northern coastal Spain the Atlantic winds dominate the transport of particulate matter inland.

Large sources of $\mathrm{SO}_{2}$ located in wet Spain region, in the north, (Fig. 4c) do not contribute efficiently to the secondary inorganic aerosol since high dispersion and removal by wet deposition are important processes in this region (not shown). In the southern part of Spain, African dust outbreaks contribute significantly to the aerosol loadings, ranging from to 10 to $20 \mu \mathrm{g} \mathrm{m}^{-3}$. The largest annual mean contribution of desert dust coincides with the Sierra Nevada mountain range with values reaching up to $30 \mathrm{\mu g} \mathrm{m}^{-3}$. Such concentrations are 
the consequences of (1) the mountain range location within the main zone of dust deposition (70\% of dust export is deposited within the first $2000 \mathrm{~km}$, Jaenicke and Schütz, 1978) and (2) the existence of several peaks within the mountain range $3000 \mathrm{~m}$ above sea level (asl) which corresponds to the altitude range for Saharan dust transport (between 1500 and $4000 \mathrm{~m}$ asl, Talbot et al., 1986; Olmo et al., 2008).

\section{Exceedances of ozone during summertime}

This section analyses the $\mathrm{O}_{3}$ exceedances during the high $\mathrm{O}_{3}$ season (from April to September) when $\mathrm{O}_{3}$ concentrations present peaks which frequently exceeded $120 \mathrm{\mu g} \mathrm{m}^{-3}$, reaching still $200 \mu \mathrm{g} \mathrm{m}^{-3}$. The target value set in the European regulation is $120 \mathrm{\mu g} \mathrm{m}^{-3}$, not to be exceeded on more than 25 days per calendar year averaged over three years (averaging as the maximum daily eighthour mean, European Commission, 2008). Fig. 8 shows the number of days exceeding the concentration value of $120 \mathrm{\mu g} \mathrm{m}^{-3}$ for the $8-\mathrm{hr}$ maximum $\mathrm{O}_{3}$ concentration and the VOCs/NOx ratio over the land domain (Fig. 8a) and over the entire domain, including the ocean (Fig. $8 \mathrm{~b}$ ). The $\mathrm{VOCs} / \mathrm{NO} x$ ratio is calculated as hourly average and is represented in logarithm scale, since the ratio ranges from 1 to $10^{6}$.

There is an overlap among ratios and number of days with exceedances. The number of exceedances is higher than 45 days where VOCs/NOx ratio is between 3 and 4.5, approximately. Such situation correspond to zones downwind main $\mathrm{NO}_{x}$ emission sources (see annual mean concentration of $\mathrm{NO}_{2}$ in Fig. 4a) from the two largesst Spanish cities (Madrid and Barcelona, see locations in Fig. 8) and industrial areas along the eastern Spanish Mediterranean coast (Tarragona, Valencia and Castellón; see locations in Fig. 8). Dynamics of pollutant during summer and primary emission sources along the eastern coast and the central plateau of the IP determinate the location of the calculated exceedances. Several studies performed over the western Mediterranean basin (e.g. Gangoiti et al., 2001; Jiménez and Baldasano, 2004; Stein et al., 2005; Jiménez et al., 2006; Jiménez-Guerrero et al., 2008b; Gonçalves et al., 2009) are in agreement with our findings. Along the coast the sea-breezes and mountain-valley winds contribute to the accumulation and recirculation of aged airmasses and $\mathrm{O}_{3}$ aloft. Besides, over the central plateau flows are dominated by the development of the IP Thermal Low (ITL). Several deep convective cells coupled with the ITL inject aged pollutant for the Madrid area and those transported previously from coastal area. On the other hand, the number of exceedances is less than 30 days for $\mathrm{VOCs} / \mathrm{NO}$ x ratio higher than 4.75 , that regime, represented in white color in Fig. 8, covers the northern and southern Spanish plateaus, where there is no high density of anthropogenic emissions. Note that a quarter of the IP presents more than 30 days exceeding the value of $120 \mathrm{\mu g} \mathrm{m}^{-3}$ for the 8-hr maximum $\mathrm{O}_{3}$ concentration.

In general, there is a significant anti-correlation $(r=-0.71)$ between $\mathrm{O}_{3}$ exceedances and the VOCs/NOx ratio for the entire domain when only the inland $\mathrm{O}_{3}$ formation is considered (Fig. 8a). For high ratios, there is a $\mathrm{NOx}$ limitation regime, and no $\mathrm{O}_{3}$ exceedances are detected because of there is not enough $\mathrm{NO} x$ available. However, when we calculate the aforementioned correlation over the entire domain, including the ocean (Fig. 8b), the anti-correlation slightly 
decreases $(r=-0.63)$ as a result of two different behaviors. First, the Strait of Gibraltar region presents the lowest $\mathrm{VOCs} / \mathrm{NO} \times$ ratio (equal to 3 ) and no exceedances are detected (see Sect. 3.2). The frequent shipping traffic and the high density of industry in the area generate important $\mathrm{NO} x$ emissions, VOCs concentrations are not high enough to produce $\mathrm{O}_{3}$, moreover the $\mathrm{O}_{3}$ loss is high due to $\mathrm{NO}_{x}$ emissions act as $\mathrm{O}_{3}$ sinks (Marmer et al., 2009). The opposite happens over the western Mediterranean basin which shows the highest VOCs/NOx ratio (over 5) and many exceeding days (more than 45). As we mentioned before, the complex layout of the coasts and surrounding mountain favors that the Mediterranean Sea acts as a reservoir of aged pollutants. Furthermore in summer the meteorological condition (high pressure, stability, clear sky and high solar radiation intensity) enhance photochemical processes and emissions of biogenic volatile organic compounds to the atmosphere $(\mathrm{NO} x$ limited regime). Not only $\mathrm{O}_{3}$ formation due to local and regional sources, but also long-range transport of European air toward the Mediterranean basin (Lelieveld et al., 2002) could be important causes of the $\mathrm{O}_{3}$ exceedances of the limit value . Furthermore dry deposition over open ocean remains near zero (not shown here). All together contribute to increase levels of $\mathrm{O}_{3}$ (lifetime typically of few weeks in summer, Seinfeld and Pandis, 1998).

\section{Conclusions}

This work presents the evaluation and the assessment of the CALIOPE air quality forecasting system (namely WRF-ARW/HERMES/CMAQ/BSCDREAM8b) for a full-year simulation for 2004 over Spain. CALIOPE was applied with high resolution (4 km $\times 4 \mathrm{~km}, 1 \mathrm{hr})$ using the HERMES emission model specifically developed for Spain. The evaluation of the modeling results for gasphase pollutants $\left(\mathrm{O}_{3}, \mathrm{NO}_{2}\right.$ and $\left.\mathrm{SO}_{2}\right)$ and particulate matter (PM10) on an hourly basis showed a strong dependency of the performance of the model on the type of zone (urban, suburban and rural) and the dominant emission sources (traffic, industrial, and background). For $\mathrm{NO}_{2}$ the best model behavior corresponds to both background rural stations and urban stations located in very large cities such as Madrid or Barcelona. With respect to $\mathrm{O}_{3}$, stations influenced by traffic emissions (i.e. high $\mathrm{NO}_{x}$ emissions) are better characterized with a more pronounced daily variability. $\mathrm{NO}_{x} / \mathrm{O}_{3}$ chemistry is better represented under nonlimited- $\mathrm{NO}_{2}$ regimes. For each station category, annual $\mathrm{O}_{3}$ (hourly and peaks) statistics meet the range defined by the USEPA and European regulation for an acceptable performance of the model. Results show that a quarter of the Iberian Peninsula is affected by more than 30 days exceeding the value of $120 \mathrm{\mu g} \mathrm{m}^{-3}$ for the 8-hr maximum $\mathrm{O}_{3}$ concentration.

The general spatial patterns and temporal characteristics simulated by CALIOPE for gas-phase pollutants and particulate matter are consistent with other studies and surveys. $\mathrm{SO}_{2}$ is mainly produced from isolated point sources (power generation and transformation industries) which generate large plumes of high $\mathrm{SO}_{2}$ concentration affecting the air quality on a local to national scale where the meteorological pattern is crucial, whereas $\mathrm{NO}_{2}$ concentration in ground level are dominated mainly by traffic emissions, which are subjected to a much stronger temporal variation than the $\mathrm{SO}_{2}$ emissions.

$\mathrm{NO}_{2}$ mean levels are persistently underestimated $\left(\mathrm{MB}=-12.3 \mu \mathrm{g} \mathrm{m}^{-3}\right)$. 
Highest errors are found in urban stations which are likely influenced by high, very local emission sources from urban activities which remain difficult to capture by models. $\mathrm{NO}_{2}$ stations located in small cities were not represented correctly by the model. We attribute such behavior to the incomplete characterization of emissions from small cities and to the influence of the model resolution on subgrid emission sources. Modeled PM10 concentrations were persistently underestimated at suburban and urban locations mostly influenced by background emissions, a common feature of most of the current regional models.

Despite the accurate performance of the modeling system, several aspects are now under further research in the framework of the CALIOPE project. Windblown dust should be taken into account since such source contributes to the underestimation of the total concentration of PM10, especially in dry and arid regions such Spain. Biomass burning, biogenic soil emissions and natural $\mathrm{NO}_{\mathrm{x}}$ are currently not treated in the CALIOPE model system, and could contribute to the $\mathrm{NO}_{2}$ underestimation. In addition, ammonia emission and particulate matter from vegetated and agricultural areas in HERMES are under a continuous improvement. Last, a new version of CMAQ is being implemented in the MareNostrum supercomputing (CMAQv4.7) featuring a new aerosol module which contains substantial scientific improvements over the aerosol modules released in version 4.5, especially devoted to improve secondary organic aerosol formation.

The present analysis demonstrates that the high spatial resolution $(4 \mathrm{~km} \times 4$ $\mathrm{km}$ ) applied in the CALIOPE forecasting system correctly address the air pollution behavior in (1) urban/industrial areas with a pervasive influence of anthropogenic emissions on a local scale, and (2) areas with very complex terrains and meteorology like southern Europe. Therefore, the system has been implemented and evaluated operationally and air quality forecasts can be found in http://www.bsc.es/caliope.

\section{Acknowledgements}

The authors wish to thank the CEAM, CIEMAT and CSIC-IJA centers for their collaboration in the project. Also, thanks to $S$. Basart and C. Pérez for providing the BSC-DREAM8b outputs and L. González for their work related to the CALIOPE system. This work is funded by the CALIOPE project of the Spanish Ministry of the Environment (441/2006/3-12.1, A357/2007/2-12.1, 157/PC08/312.0). The Spanish Ministry of Science and Innovation is also thanked for the Formación de Personal Investigador (FPI) doctoral fellowship held by María Teresa Pay (CGL2006-08903). All simulations were performed on the MareNostrum supercomputer hosted by the Barcelona Supercomputing Center.

\section{References}

Amann, M., Bertok, I., Cofala, J., Gyarfas, F., Heyes, C., Klimont, Z., Schöpp, W., Winiwarter, W., 2004. Baseline Scenarios for the Clean Air for Europe (CAFE) Programme. Technical Report. European Commission, DG Environment, Dir. C Environment and Health. 
Amato, F., Pandolfi, M., Escrig, A., Querol, X., Alastuey, A., Pey, J., Pérez, N., Hopke, P.K., 2009a. Quantifying road dust resuspension in urban environment by multilinear engine: A comparison with pmf2. Atmos. Environ. 43, 2770-2780.

Amato, F., Pandolfi, M., Viana, M., Querol, X., Alastuey, A., Moreno, T., 2009b. Spatial and chemical patterns of $\mathrm{PM}_{10}$ in road dust deposited in urban environment. Atmos. Environ. 43, 1650-1659.

Amato, F., Nava, S., Lucarelli, F., Querol, X., Alastuey, A., Baldasano, J.M., Pandolfi, M., 2010. A comprehensive assessment of PM emissions from paved roads: Real-world Emission Factors and intense street cleaning trials. Sci. Tot. Env. 408, 4309-4318.

Baldasano, J.M., Cremades, L., Soriano, C., 1994. Circulation of air pollutants over the Barcelona geographical area in summer. Proceedings of Sixth European Symposium Physic-Chemical Behavior of Atmospheric Pollutants. Varese (Italy), 18-22 October, 1993. Report EUR 15609/ EN: 474479.

Baldasano, J.M., Jiménez-Guerrero, P., Jorba, O., Pérez, C., López, E., Güereca, P., Martín, F., Vivanco, M.G., Palomino, I., Querol, X., Pandolfi, M., Sanz, M.J., Diéguez, J.J., 2008a. Caliope: an operational air quality forecasting system for the Iberian Peninsula, Balearic Islands and Canary Islands - first annual evaluation and ongoing developments. Adv. Sci. Res. 2, 89-98.

Baldasano, J.M., Güereca, L.P., López, E., Gassó, S., Jiménez-Guerrero, P., 2008b. Development of a high-resolution ( $1 \mathrm{~km} \times 1 \mathrm{~km}, 1 \mathrm{~h})$ emission model for Spain: The High-Elective Resolution Modelling Emission System (HERMES). Atmos. Environ. 42, 7215-7233.

Binkowski, F.S., 1999. Aerosols in models-3 cmaq, in: Byun, D.W., Ching, J.K.S. (Eds.), Science Algorithms of the EPA Models-3 Community Multiscale Air Quality (CMAQ) Modeling System, EPA. pp. 10-23.

Binkowski, F.S., Roselle, S.J., 2003. Models-3 community multiscale air quality (cmaq) model aerosol component. 1. model description. J. Geophys. Res. 108 (D6), 4183, doi:10.1029/2001JD001409.

Binkowski, F.S., Shankar, U., 1995. The regional particulate model 1. model description and preliminary results. J. Geophys. Res. 100 (D12), 26191-26209.

Boylan, J., Russell, A., 2006. Pm and light extinction model performance metrics, goals, and criteria for three-dimensional air quality models. Atmos. Environ. 40, 4946-4959.

Brunekreef, B., Holgate, S.T., 2002. Air pollution and health. Lancet 360 (9341), 1233-1242, doi:10.1016/S0140-6736(02)11274-8.

Byun, D., Schere, K.L., 2006. Review of the governing equations, 
computacional algorithms, and other components of the Models-3 Community Multiscale Air Quality (CMAQ) modeling system. Appl. Mech. Rev. 59 (2), 51-77.

Byun, D.W., Ching, J.K.S., 1999. Science algorithms of the EPA Models-3 Community Multiscale Air Quality (CMAQ) modeling system. Atmospheric modeling division, National Exposure Research Laboratory, US Environmental Protection Agency, Research Triangle Park, NC 27711.

Chang, J.C., Hanna, S.R., 2004. Air quality model performance evaluation. Meteorol. Atmos. Phys. 87, 167-196.

Ching, J., Herwehe, J., Swall, J., 2006. On joint deterministic grid modeling and sub-grid variability conceptual framework for model evaluation. Atmos. Environ. 40, 4935-4945.

Corbett, J.J., Fischbeck, P., 1997. Emissions from ships. Science 278 (5339), 823-824, doi:10.1126/science.278.5339.823.

Corbett, J.J., Koehler, H.W., 2003. Updated emissions from ocean shipping. J. Geophys. Res. 108 (D20), 4650, doi:10.1029/2003JD003751.

Cox, W.M., Tikvart, J.A., 1990. Statistical procedure for determining the best performing air quality simulation model. Atmos. Environ. 24, 2387-2395.

Cristofanelli, P., Bonasoni, P., 2009. Background ozone in the southern Europe and Mediterranean area: Influence of the transport processes. Env. Poll. 157, 1399-1406.

Cuvelier, C., Thunis, P., Vautard, R., Amann, M., Bessagnet, B., Bedogni, M., Berkowicz, R., Brandt, J., Brocheton, F., Builtjes, P., Carnavale, C., Coppalle, A., Denby, B., Douros, J., Graf, A., Hellmuth, O., Hodzic, A., Honoré, C., Jonson, J., Kerschbaumer, A., de Leeuw, F., Minguzzi, E., Moussiopoulos, N., Pertot, C., Peuch, V.H., Pirovano, G., Rouil, L., Sauter, F., Schaap, M., Stern, R., Tarrason, L., Vignati, E., Volta, M., White, L., Wind, P., Zuber, A., 2007. Citydelta: A model intercomparison study to explore the impact of reductions in European cities in 2010. Atmos. Environ. 41, 189-207.

Denby, B., Larssen, S., Guerreiro, C., Li, L., Douros, J., Moussiopoulos, N., Fragkou, L., Gauss, M., Olesen, H., Miranda, A.I., Georgieva, E., Dilara, P., Lappi, S., Rouil, L., Lükeville, A., Querol, X., Martin, F., Schaap, M., van den Hout, D., Kobe, A., 2009. Guidance on the use of models for the European Air Quality Directive. A working document of the Forum for Air Quality Modelling in Europe FAIRMODE. Technical Report Version 4.2, Editor B. Denby. ETC/ACC report.

Düring, I., Jacob, J., Lohmeyer, A., Lutz, M., Reichenbächer, W., 2002. Estimation of the "non-exhaust pipe" PM10 emissions of streets for practical traffic air pollution modelling, in: 11th Intl. Symposium TRANSPORT and AIR POLLUTION, Graz University of Technology, Institute for Internal Combustion Engines and Thermodynamics. pp. 309-316, vol. 1. 
EEA, 2005. Air pollution by ozone in Europe in summer 2004. Technical Report. 3/2005, Copenhagen, Denmark. http://reports.eea.eu.int.

EEA, 2009a. Air pollution by ozone across Europe during summer 2008. Technical Report. 2/2009, Copenhagen, Denmark. http://reports.eea.eu.int.

EEA, 2009b. Spatial assessment of $\mathrm{PM} 10$ and ozone concentrations in Europe (2005). Technical Report. 1/2009, Copenhagen, Denmark. http://reports.eea.eu.int.

EEA, 2010. Air pollution by ozone across Europe during summer 2009. Technical Report. 2/2010, Copenhagen, Denmark. http://reports.eea.eu.int.

European Commission, 2008. Directive 2008/50/EC of the European Parliament and of the Council of 21 May 2008 on ambient air quality and cleaner air for Europe. Technical Report 2008/50/EC, L152. Off. J. Eur. Comm.

Fishman, J., Crutzen, P., 1978. The origin of ozone in the troposphere. Nature 274, 855-858.

Folberth, G., Hauglustaine, D.A., Lathière, J., Brocheton, J., 2006. Interactive chemistry in the laboratoire de météorologie dynamique general circulation model: model description and impact analysis of biogenic hydrocarbons on tropospheric chemistry. Atmos. Chem. Phys. 6, 2273-2319.

Gangoiti, G., Millán, M., Salvador, R., Mnatilla, E., 2001. Long-range transport and re-circulation of pollutants in the western Mediterranean during the project regional cycles of air pollution in the west-central Mediterranean area. Atmos. Environ. 35, 6267-6276.

Garber, W., Colosio, J., Grittner, S., Larssen, S., Rasse, D., Schneider, J., Housiau, M., 2002. Guidance on the Annexes to Decision 97/101/EC on Exchange of Information as revised by Decision 2001/752/EC. Technical Report. European Commission, DG Environment.

Gerasopoulos, E., Kouvarakis, G., Vrekoussis, M., Kanakidou, M., Mihalopoulos, N., 2005. Ozone variability in the marine boundary layer of the eastern Mediterranean based on 7-year observations. J. Geophys. Res. 110, D15309.

Gery, M.W., Whitten, G.Z., Killus, J.P., Dodge, M.C., 1989. A photochemical kinetics mechanism for urban and regional scale computer modeling. J. Geophys. Res. 94 (D10), 12925-12956.

Gonçalves, M., Jiménez-Guerrero, P., Baldasano, J., 2009. Contribution of atmospheric processes affecting the dynamics of air pollution in south-western Europe during a typical summertime photochemical episode. Atmos. Chem. Phys. 9, 849-864. 
Gong, S.L., 2003. A parameterization of sea-salt aerosol source function for sub- and super-micron particles. J. Geophys. Res. 17, 1097, doi:10.1029/2003GB002079.

Gryparis, A., Forsberg, B., Katsouyanni, K., Analitis, A., Touloumi, G., Schwartz, J., Samoli, E., Medina, S., Anderson, H.R., Niciu, E.M., Wichmann, H.E., Kriz, B., Kosnik, M., Skorkovsky, J., Vonk, J.M., Dörtbudak, Z., 2004. Acute effects of ozone on mortality from the air pollution and health: A European approach project. Amer. J. Resp. Crit. Care Med. 170 (10), 1080-1087.

Hauglustaine, D.A., Hourdin, F., Jourdain, L., Filiberti, M.A., Walters, S., Lamarque, J.F., Holland, E.A., 2004. Interactive chemistry in the laboratoire de meteorologie dynamique general circulation model: Description and background tropospheric chemistry evaluation. J. Geophys. Res. D4 (D04314), doi:10.1029/2003JD003,957.

International Maritime Organization and Marine Environment Protection Committee, 2001. Prevention of air pollution from ships-Sulfur monitoring 2000. Technical Report. London.

Jaenicke, R., Schütz, L., 1978. Comprehensive study of physical and chemical properties of the surface aerosols in the Cape Verde islands region. J. Geophys. Res. 83 (C7), 3585-3599.

Janjic, Z.I., 1994. The step-mountain ETA coordinate model: Further developments of the convection, viscous sublayer and turbulence closure schemes. Mon. Weather Rev. 122, 927-945.

Jiménez, P., Baldasano, J.M., Dabdub, D., 2003. Comparison of photochemical mechanisms for air quality modelling. Atmos. Environ. 37 (30), 4179-4194, doi:10.1016/S1352-2310(03)00567-3.

Jiménez, P., Baldasano, J.M., 2004. Ozone response to precursor controls in very complex terrains: Use of photochemical indicators to assess $\mathrm{O}_{3}-\mathrm{NO}_{\mathrm{x}}-\mathrm{VOC}$ sensitivity in the northeastern Iberian Peninsula. Journal of Geophysical Research 109, D20309, doi: 10.1029/2004JD004985.

Jiménez, P., Lelieveld, J., Baldasano, J.M., 2006. Multi-scale modeling of air pollutants dynamics in the northwestern Mediterranean basin during a typical summertime episode. J. Geophys. Res. 111, (D18306), 1-21, doi:10.1029/2005JD006516.

Jiménez-Guerrero, P., Jorba, O., Baldasano, J.M., Gassó, S., 2008. The use of a modelling system as a tool for air quality management: Annual high resolution simulations and evaluation. Sci. Tot. Env. 390, 323-340.

Jiménez-Guerrero, P., Pérez, C., Jorba, O., Baldasano, J.M., 2008. Contribution of Saharan dust in an integrated air quality system and its on-line assessment. Geophys. Res. Lett. 35 (L03814), doi:10.1029/2007GL031580. 
Lam, Y.F., Fu, J.S., 2009. A novel downscaling technique for the linkage of global and regional air quality modeling. Atmos. Chem. Phys. 9, 9169-9185.

de Leeuw, F., Vixseboxse, E., 2010. Reporting on ambient air quality assessment - Preliminary results for 2008. Technical Report. The European Topic Centre on Air and Climate Change (ETC/ACC) Technical Paper 2009/10.

Lelieveld, J., Berresheim, H., Borrmann, S., Crutzen, P.J., Dentener, F.J., Fischer, H., Feichter, J., Flatau, P.J., Heland, J., Holzinger, R., Korrmann, R., Lawrence, M.G., Levin, Z., Markowicz, K.M., Mihalopoulos, N., Minikin, A., Ramanathan, V., de Reus, M., Roelofs, G.J., Scheeren, H.A., Sciare, J., Schlager, H., Schultz, M., Siegmund, P., Steil, B., Stephanou, E.G., Stier, P., Traub, M., Warneke, C., Williams, J., Ziereis, H., 2002. Global air pollution crossroads over the Mediterranean. Science 298, 794-799.

Lenschow, P., Abraham, H.J., Kutzner, K., Lutz, M., Preuß, J.D., Reichenbächer, W., 2001. Some ideas about the sources of PM10. Atmos. Environ. 35, Supplement No. 1, S23.

Linares, P., Romero, C., 2000. A multiple criteria decision making approach for electricity planning in Spain: economic versus environmental objectives. J. Oper. Res. Soc. 51 (6), 736-743.

LUA, 2000. Vorgehensweise bei der Schwebstaubimmissionsberechnung nach Richtlinie 1999/30/EG. Technical Report. Landesumweltamt Brandenburg, Entwurf des Referats I3 vom 21.12.2000.

Manders, A., Schaap, M., Querol, X., Albert, M.F.M.A., Vercauteren, J., Kuhlbusch, T.A.J., Hoogerbrugge, R., 2010. Sea salt concentrations across the European continent. Atmos. Environ., in press.

Marmer, E., Dentener, F., Aardenne, J., Cavalli, F., Vignati, E., Velchev, K., Hjorth, J., Boersma, F., Vinken, G., Mihalopoulos, N., Raes, F., 2009. What can we learn about ship emission inventories from measurements of air pollutants over the Mediterranean Sea? Atmos. Chem. Phys. Discuss. 9, 7155-7211.

Menut, L., Bessagnet, B., 2010. Atmospheric composition forecasting in Europe. Annals Geoph. 28, 61-74.

Michalakes, J., Dudhia, J., Gill, D., Henderson, T., Klemp, J., Skamarock, W., Wang, W., 2004. The weather research and forecast model: Software architecture and performance, in: Mozdzynski, E.G. (Ed.), To appear in proceeding of the Eleventh ECMWF Workshop on the Use of High Performance Computing in Meteorology, 2529 October 2004, Reading, U.K.. p. 117-124.

Millán, M.M., Salvador, R., Mantilla, E., 1997. Photooxidant dynamics in the Mediterranean Basin in Summer: Results from European Research Projects. J. Geophys. Res. 102(D7), 8811-8823.

Millán, M.M., 2002a. Ozone Dynamics in the Mediterranean Basin, A 
collection of scientific papers resulting from the MECAPIP, RECAPMA and SECAP Projects. Technical Report. European Commission and CEAM.

Millán, M.M., Sanz, M.J., Salvador, R., Mantilla, E., 2002b. Atmospheric dynamics and ozone cycles related to nitrogen deposition in the western Mediterranean. Energy Policy 118, 167-186.

Nenes, A., Pilinis, C., Pandis, S.N., 1998. ISORROPIA: A new thermodynamic equilibrium model for multiphase multicomponent inorganic aerosols. Aquatic Geochemistry 4 (1), 123-152, doi:10.1023/A:1009604003981.

Nickovic, S., Kallos, G., Papadopoulos, A., Kakaliagou, O., 2001. A model for prediction of desert dust cycle in the atmosphere. J. Geophys. Res. 106 (D16), 18113-18129, doi:10.1029/2000JD900794.

Olmo, F.J., Quitantes, A., Lara, V., Lyamani, H., Alados-Arboledas, L., 2008. Aerosol optical properties assessed by an inversion method using the solar principal plane for non-spherical particles. J. Quant. Spectrosc. Radiat. Transfer 109, 1504-1516.

Ortiz de Zárate, I., Ezcurra, A., Lacaux, J.P., Dinh, P.V., de Argandoña, J.D., 2005. Pollution by cereal waste burning in Spain. Atmos. Res. 73 (1-2), 161-170, doi:10.1016/j.atmosres.2004.07.006.

Pay, M.T., Piot, M., Jorba, O., Basart, S., Gassó, S., Jiménez-Guerrero, P., Gonçalves, M., Dabdub, D., Baldasano, J.M., 2010. A full year evaluation of the CALIOPE-EU air quality system in Europe for 2004: a model study. Atmos. Environ., doi:10.1016/j.atmosenv.2010.050140.

Pénard-Morand, C., Charpi, D., Raherison, C., Kopferschmitt, C., Caillaud, D., Lavaud, F., Annesi-Maesano, I., 2005. Long-term exposure to background air pollution related to respiratory and allergic health in schoolchildren. Clin. Exp. Allergy 35 (10), 1279-1287, doi:10.1111/j.1365-2222.2005.02336.

Pérez, C., Nickovic, S., Baldasano, J.M., Sicard, M., Rocadenbosch, F., Cachorro, V.E., 2006a. A long Saharan dust event over the western Mediterranean: Lidar, sun photometer observations, and regional dust modeling. J. Geophys. Res. 111 (D15214), 1-16, doi:10.1029/2005JD006579.

Pérez, C., Nickovic, S., Pejanovic, G., Baldasano, J.M., Ozsoy, E., 2006b. Interactive dust-radiation modeling: A step to improve weather forecasts. J. Geophys. Res. 111 (D16206), doi:10.1029/2005JD006717, 1-17.

Querol, X., Alastuey, A., Moreno, T., Viana, M.M., Castillo, S., Pey, J., Rodríguez, S., Artiñano, B.A., Salvador, P., Sánchez, M., Santos, S.G.D., Garraleta, M.D.H., Fernandez-Patier, R., Moreno-Grau, S., Negral, L., Minguillón, M.C., Monfort, E., Sanz, M.J., Palomo-Marín, R., Pinilla-Gil, E., Cuevas, E., de la Rosa, J., de la Campa, A.S., 2008. Spatial and temporal variations in airborne particulate matter (PM10 and $\left.\mathrm{PM}_{2}: 5\right)$ across Spain 19992005. Atmos. Environ. 42 (17), 396-3979, doi:10.1016/j.atmosenv.2006.10.071. 
Querol, X., Alastuey, A., Rodríguez, S., Plana, F., Ruiz, C.R., Cots, N., Massagué, G., Puig, O., 2001. PM10 and PM2:5 source apportionment in the Barcelona metropolitan area, Catalonia, Spain. Atmos. Environ. 35 (36), 64076419.

Querol, X., Alastuey, A., Rodríguez, S., Viana, M.M., Artiñano, B.A., Salvador, P., Mantilla, E., Santos, S.G.D., Patier, R.F., Rosa, J.D.L., Campa, A.S.D.L., Menedez, M., 2003. Estudio y evaluación de la contaminación atmosférica por material particulado en España: Informes finales. Technical Report. IJA CSIC, ISCIII, CIEMAT, Universidad de Huelva, Universidad del País Vasco.

Querol, X., Alastuey, A., Rodríguez, S., Viana, M.M., Artiñano, B.A., Salvador, P., Mantilla, E., do Santos, S.G., Patier, R.F., de La Rosa, J., de la Campa, A.S., Menéndez, M., Gil, J.J., 2004a. Levels of particulate matter in rural, urban and industrial sites in Spain. Sci. Tot. Env. 334-335, 359-376, doi:10.1016/j.scitotenv.2004.04.036.

Querol, X., Alastuey, A., Ruiz, C.R., Artiñano, B., Hansson, H.C., Harrison, R.M., Buringh, E., ten Brink, H.M., Lutz, M., Bruckmann, P., Straehl, P., Schneider, J., 2004b. Speciation and origin of $\mathrm{PM}_{10}$ and $\mathrm{PM}_{2: 5}$ in selected European cities. Atmos. Environ. 38, 6547-6555.

Rauterberg-Wulff, 2000. Untersuchung über die Bedeutung der Staubaufwirbelung für die PM10-Immission an einer Hauptverkehrsstraße. Technical Report. Techn. Univ. Berlin, Fachgebiet Luftreinhaltung.

Rodríguez, S., Querol, X., Alastuey, A., Plana, F., 2002. Sources and processes affecting levels and composition of atmospheric aerosol in the western Mediterranean. J. Geophys. Res. 107 (D24), 4777.

Russell, A., Dennis, R., 2000. NARSTO critical review of photochemical models and modeling. Atmos. Environ. 34 (12-14), 2283-2324, doi:10.1016/S1352-2310(99)00468-9.

San José, R., Rodriguez, M.A., Cortés, E., González, R.M., 1999. Emma model: an advanced operational mesoscale air quality model for urban and regional environments. Environ. Manag. Health 10 (4), 258-266.

Schell, B., Ackermann, I.J., Hass, H., Binkowski, F.S., Ebel, A., 2001. Modeling the formation of secondary organic aerosol within a comprehensive air quality model system. J. Geophys. Res. 106 (D22), 28275-28293, doi:2001JD000384.

Seinfeld, J.H., Pandis, S.N., 1998. Atmospheric Chemistry and Physics. John Wiley \& Sons, New York, Chichester, Weinheim.

Skamarock, W.C., Klemp, J.B., 2008. A time-split nonhydrostatic atmospheric model for weather research and forecasting applications. J. Comput. Phys. 227 


\section{(7), 3465-3485, doi:10.1016/j.jcp.2007.01.037.}

Slemr, F., Seiler, W., 1984. Field measurement of NO and NO2 emissions from fertilized and unfertilized soils. J. Atmos. Chem. 2, 1-24.

Smith, S.N., Mueller, S.F., 2010. Modeling natural emissions in the community multiscale air quality (CMAQ) model - part 1: Building an emissions data base. Atmos. Chem. Phys. Discuss. 10, 1755-1821.

Stein, A., Mantilla, E., Millán, M., 2005. Using measured and modeled indicators to assess ozone- $\mathrm{NO}_{\mathrm{x}}-\mathrm{VOC}$ sensitivity in a western Mediterranean coastal environment. Atmos. Environ. 39, 7167-7180.

Talbot, R.W., Harriss, R.C., Browell, E.V., Gregory, G.L., Sebacher, D.I., Beck, S.M., 1986. Distribution and geochemistry of aerosols in the tropical north atlantic troposphere: Relationship to Saharan dust. J. Geophys. Res. 91 (D4), 51735182.

US-EPA, 1984. Interim procedures for evaluating air quality models (revised). Technical Report. EPA-450/4-91-013. U.S. Environmental Protection Agency, Office of Air Quality Planning and Standards: Research Triangle Park, NC.

US-EPA, 1991. Guideline for regulatory application of the urban airshed model. Technical Report. EPA-450/4-91-013. U.S. Environmental Protection Agency, Office of Air Quality Planning and Standards: Research Triangle Park, NC.

US-EPA, 1997. AP-42, 5. Edition, Volume 1, Chapter 13, Section 13.2.1. Miscellaneous sources. Technical Report. U.S. Environmental Protection Agency.

US-EPA, 2007. AP-42. $5^{\text {th }}$ Edition, Volume VI, Chapter 13, Section 13.2.1. Paved Roads. Technical Report. U.S.-Environmental Protection Agency. USEPA, 2007. Guidance on the Use of Models and Other Analyses for Demonstrating Attaintment of Air Quality Goals for Ozone, PM2.5, and Regional Haze. Technical Report. EPA-454/B-07-002. U.S. Environmental Protection Agency, Office of Air Quality Planning and Standards: Research Triangle Park, NC.

Vautard, R., Bessagnet, B., Chin, M., Menut, L., 2005a. On the contribution of natural aeolian sources to particulate matter concentrations in Europe: Testing hypotheses with a modelling approach. Atmos. Environ. 39 (18), 3291-3303, doi:10.1016/j.atmosenv.2005.01.051.

Vautard, R., Honoré, C., Beekmann, M., Rouïl, L., 2005b. Simulation of ozone during the august 2003 heat wave and emission control scenarios. Atmos. Environ. 39 (16), 2957-2967, doi:10.1016/j.atmosenv.2005.01.039.

Venkatram, A., 2000. A critique of empirical emission factor models: a case study of the AP-42 model for estimating pm10 emissions from paved roads. 
Atmos. Environ. 34, 1-11.

Venkatram, A., Pleim, J., 1999. The electrical analogy does not apply to modeling dry deposition of particles. Atmos. Environ. 33 (18), 3075-3076, doi:10.1016/S1352-2310(99)00094-1.

Viana, M., Pérez, C., Querol, X., Alastuey, A., Nickovic, S., Baldasano, J.M., 2005. Spatial and temporal variability of $P M$ levels and composition in a complex summer atmospheric scenario in Barcelona (NE Spain). Atmos. Environ. 39, 5343-5361.

Vivanco, M.G., Correa, M., Azula, O., Palomino, I., Martin, F., 2008. Influence of model resolution on ozone predictions over Madrid area (Spain), in: Computer Science, L.N. (Ed.), Computational Science and Its Applications ICCSA 2008, Springer Berlin/Heidelberg. pp. 165-178.

Vivanco, M.G., Palomino, I., Vautard, R., Bessagnet, B., Martín, F., Menut, L., Jiménez, S., 2009. Multi-year assessment of photochemical air quality simulation over Spain. Environ. Modell. Softw. 24, 63-73.

Weil, J.C., Sykes, R.I., Venkatram, A., 1992. Evaluating air-quality models: review and outlook. J. Appl. Met. 31, 1121-1145.

Zhang, K., Knipping, E., Wexler, A., Bhave, P., Tonnesen, G., 2005. Size distribution of sea-salt emissions as a function of relative humidity. Atmos. Environ. 39, 3373-3379. 


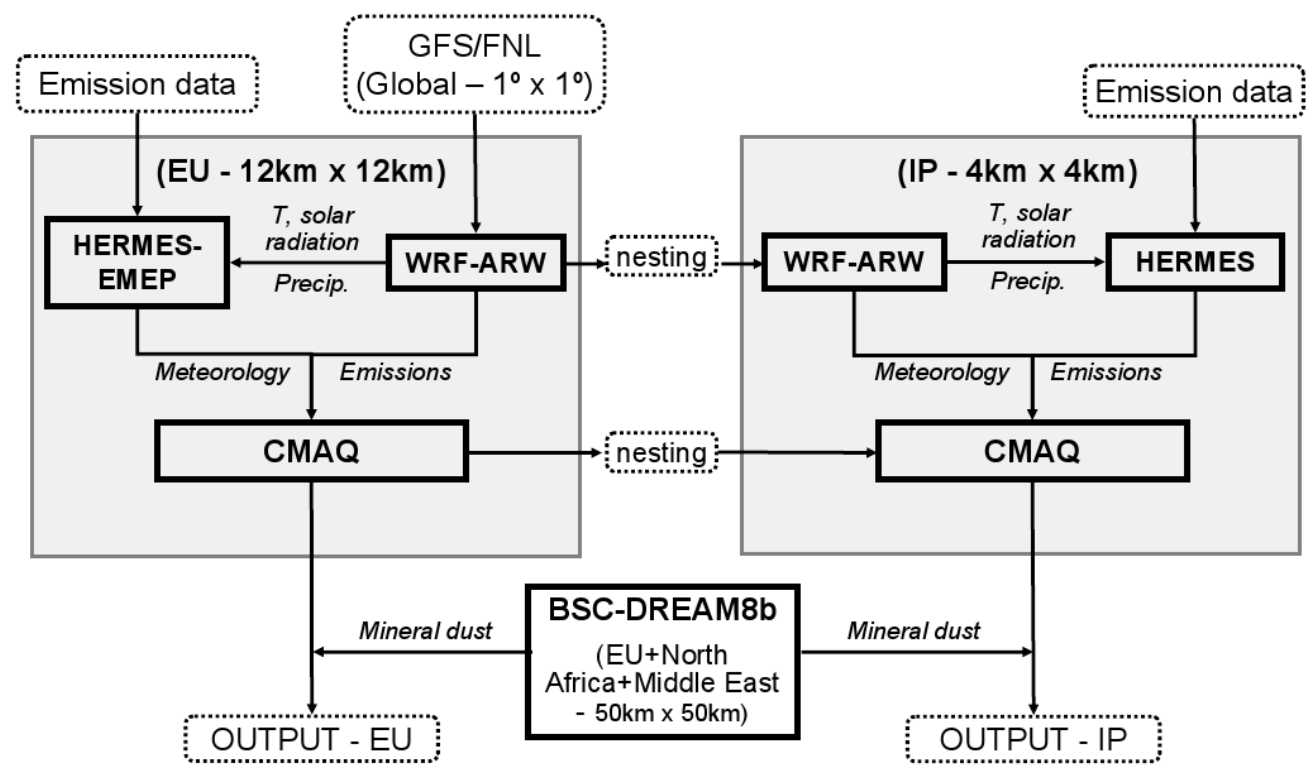

Figure 1: Modular structure of the CALIOPE modeling system used to simulate air quality dynamics in Spain. Squared boxes with solid lines represent the main models of the framework. Boxes with dashed lines represent input/output dataset. Lines connecting boxes represent the information flow. 


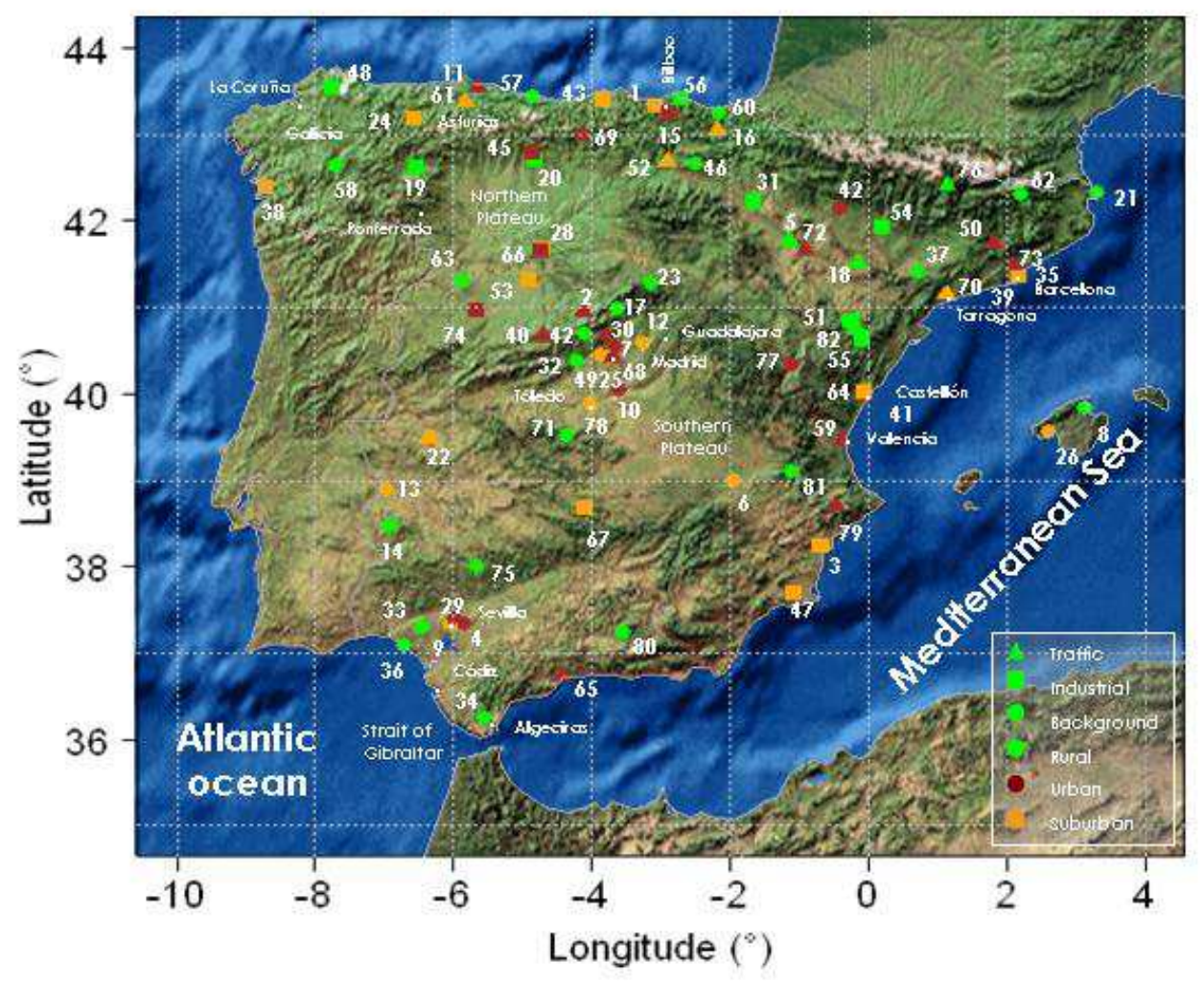

Figure 2: RedESP stations measuring air pollutants in Spain on an hourly basis in 2004. Different types of stations (U: Urban; S: Suburban; R: Rural; B: Background; I: Industrial; and T: Traffic) according to Garber et al. (2002) are represented by symbols and color codes. The various symbols represent the major emission types affecting each station (Traffic: triangle; Industrial: square; and Background: circle) while the colors reflect the environment of each station (Urban: red; Suburban: green; and Rural: orange). Characteristics and number of each station are listed in Tab. 1. 

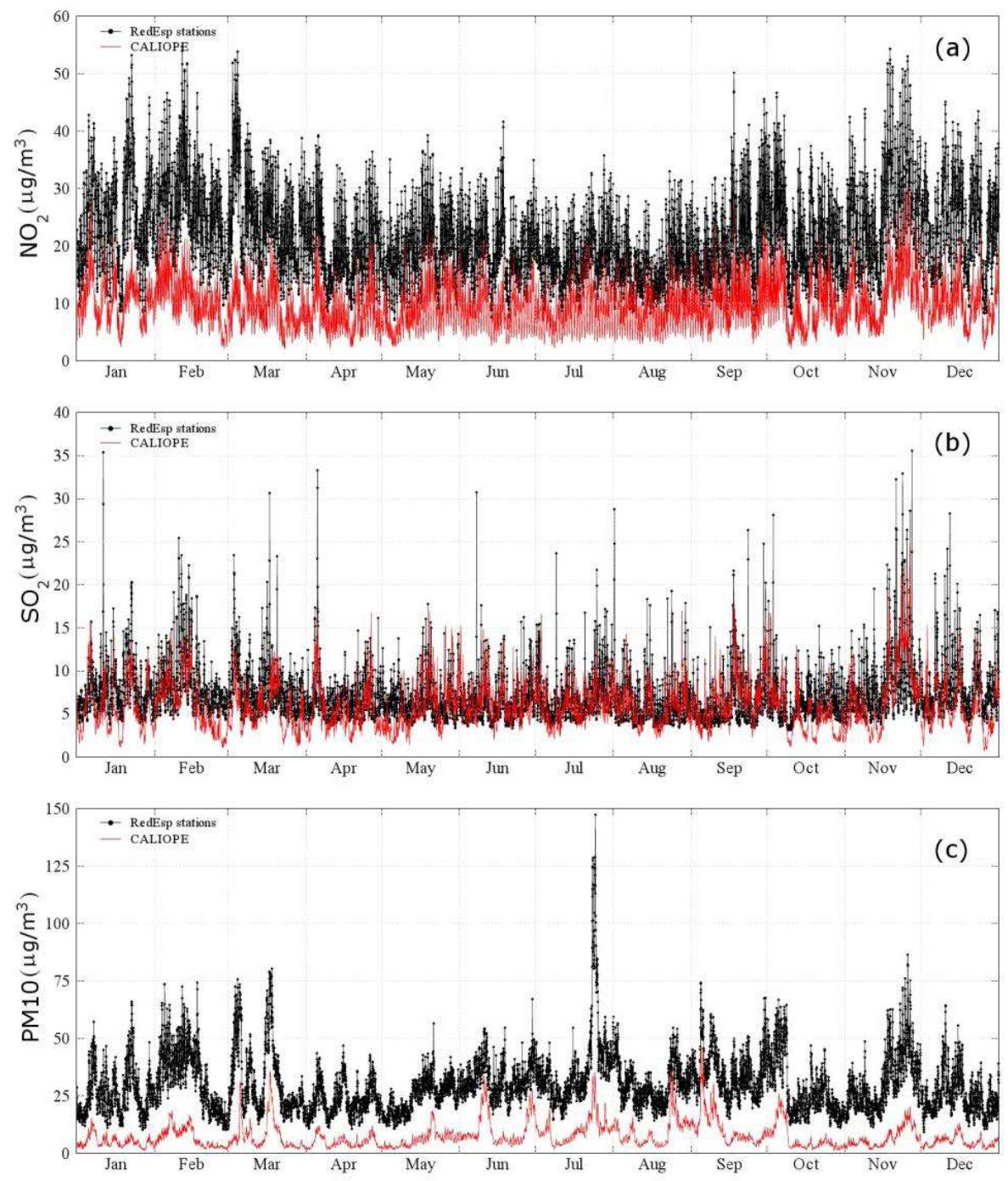

Figure 3: Modeled (red lines) and measured (marked black lines) time series of hourly mean concentrations (in $\mathrm{g} \mathrm{m} \mathrm{m}^{-3}$ ) for $\mathrm{NO}_{2}$ (a), $\mathrm{SO}_{2}$ (b) and PM10 (c), respectively, at the RedESP stations. 

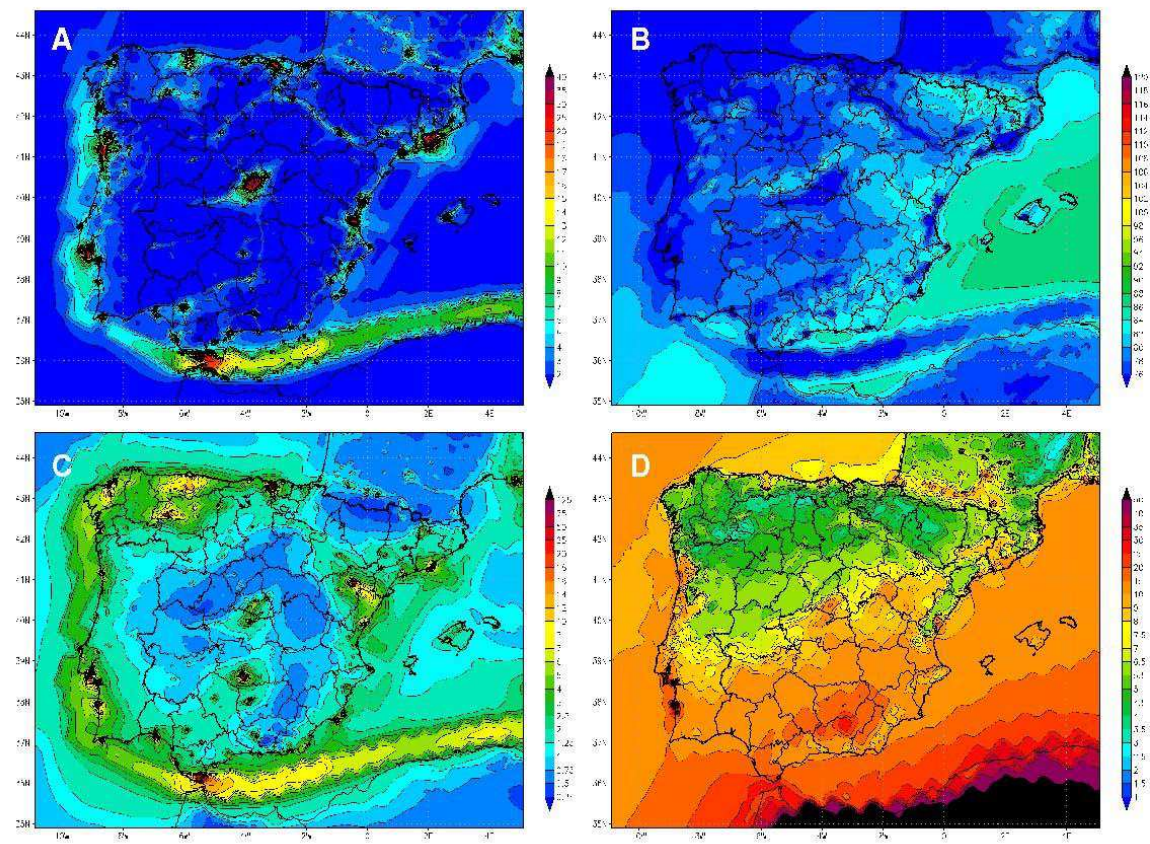

Figure 4: 2004 annual average concentrations $\left(\mu \mathrm{g} \mathrm{m}^{-3}\right)$ of (a) NO2, (b) O3, (c) SO2, (d) PM10 at ground level simulated by CALIOPE over Spain at a $4 \mathrm{~km} \times 4 \mathrm{~km}$ spatial resolution. 

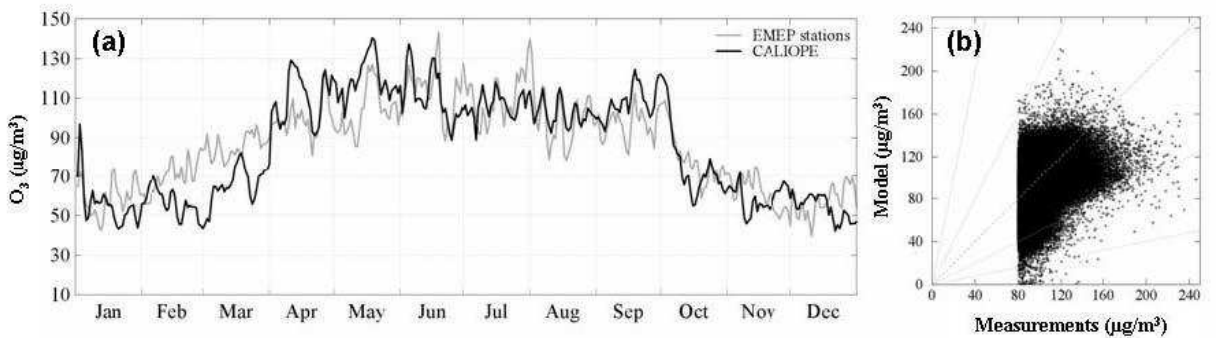

Figure 5: Modeled (black lines) and measured (grey lines) time series of daily peak concentrations (a) and scatter plots in hourly basis (b) for O3 at the RedESP stations. The scatter plot includes the $1: 1,1: 2,1: 5$, and $5: 1$ reference lines. A cut-off value of $80 \mu \mathrm{g} \mathrm{m}^{-3}$ is applied to the observation in the scatter plot. 

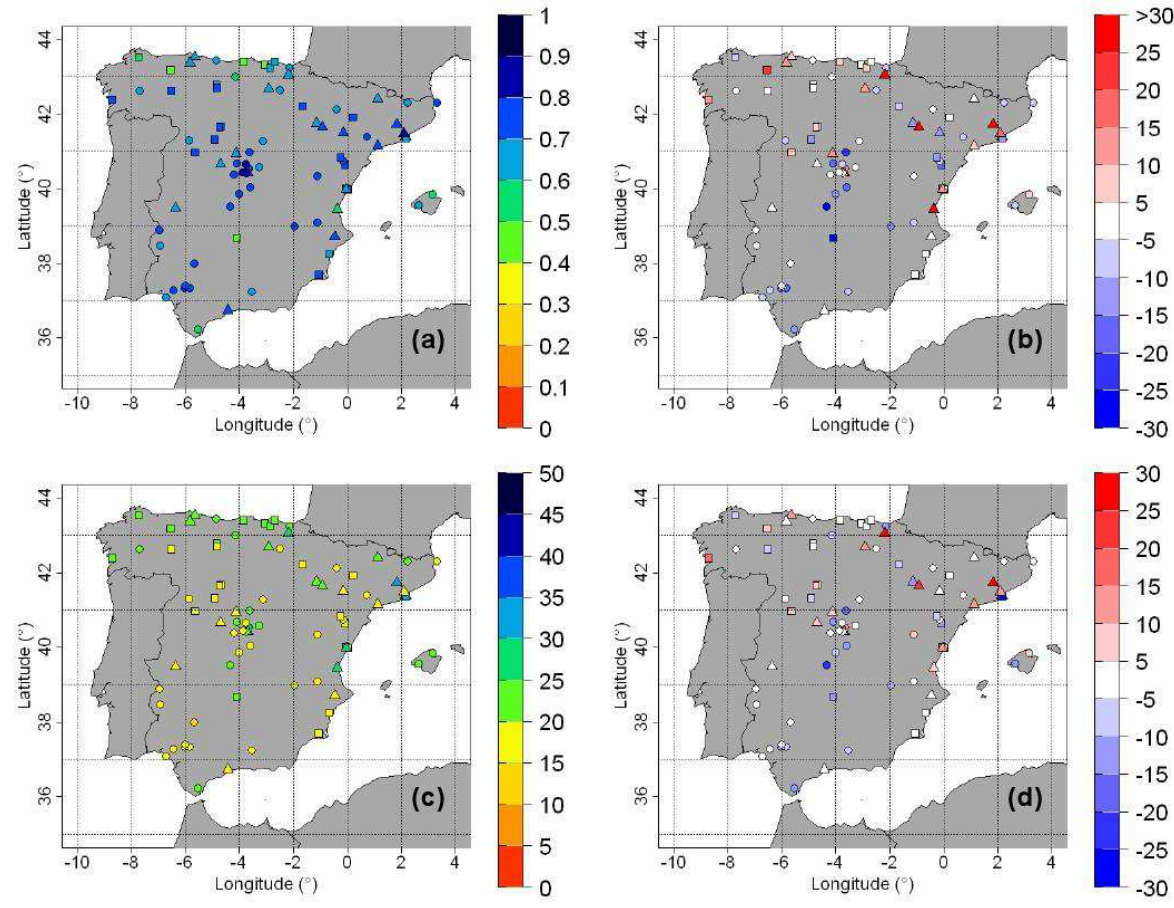

Figure 6: Spatial distribution of the statistics for $\mathrm{O}_{3}$ over 2004 at the RedESP stations: daily peak correlation coefficient ( $r$ ) (a), annual Mean Bias (MB, in $\mu \mathrm{g} \mathrm{m}^{-3}$ ) for daily peak (b), Mean Normalized Gross Error (MNGE, in \%) in hourly basis (c), and Mean Normalized Bias Error (MNBE, in \%) in hourly basis (d). Note that MB, MNGE and MNBE are calculated with a $80 \mathrm{\mu g} \mathrm{m}^{-3}$ cut-off according to US-EPA (1991) and Russell and Dennis (2000). 


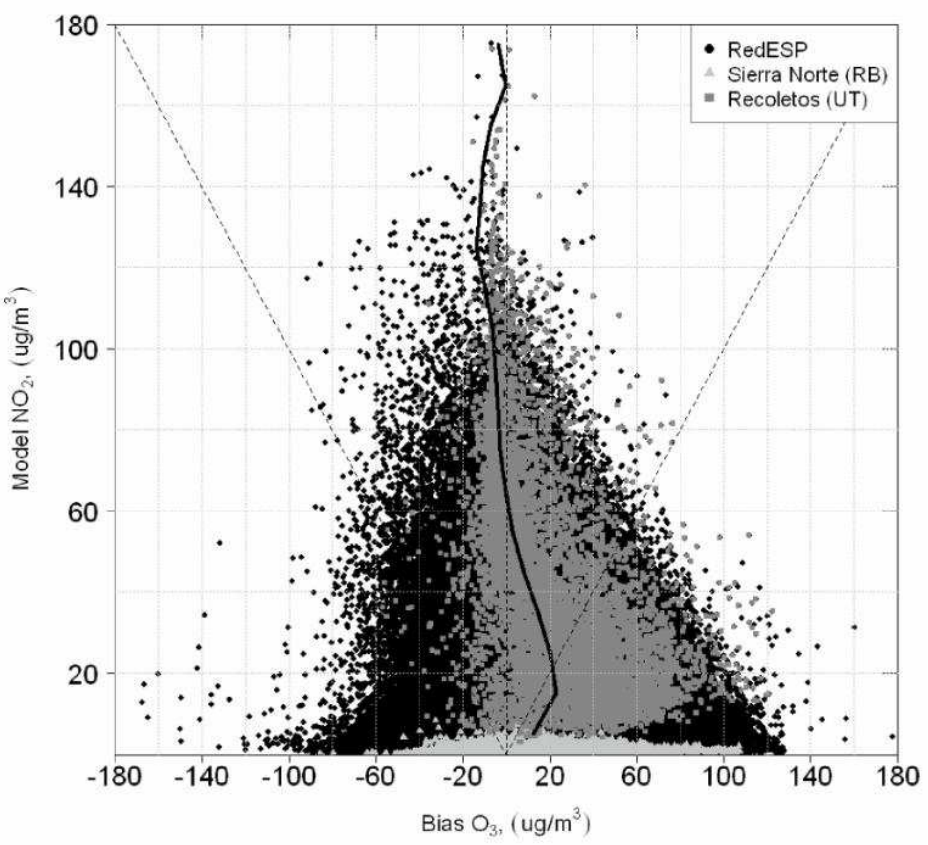

Figure 7: Modeled $\mathrm{NO}_{2}$ levels versus model-observation $\mathrm{O}_{3}$ bias. The 68 stations measuring both $\mathrm{NO}_{2}$ and $\mathrm{O}_{3}$ are represented on an hourly basis (black dots). Data from Sierra Norte, a rural background station (light grey triangles) and Recoletos, urban traffic (dark grey squares) are also displayed. The vertical black curve represents the average concentration on the X-axis every $10 \mu \mathrm{g}$ $\mathrm{m}^{-3}$ from the vertical axis. 

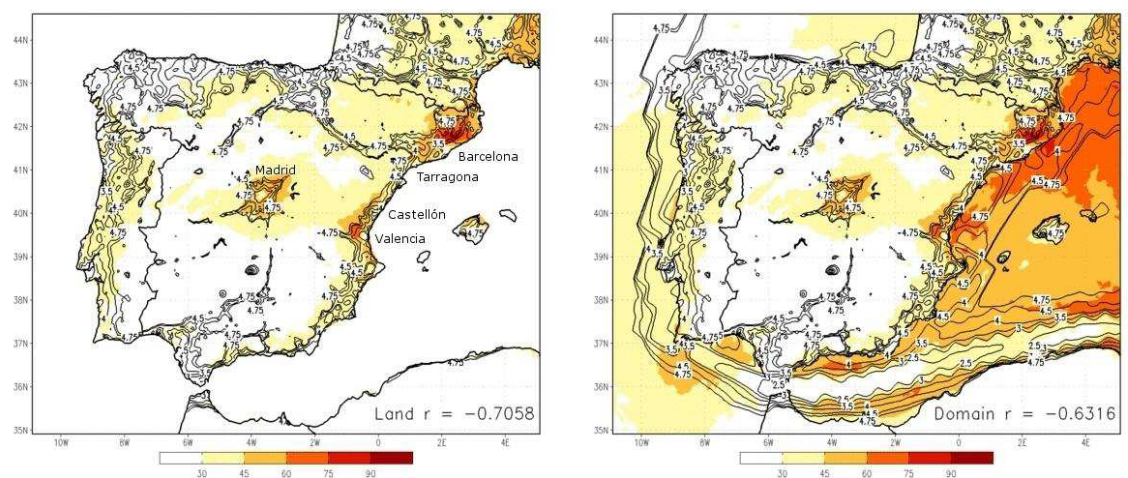

Figure 8: Days exceeding the concentration value of $120 \mathrm{\mu g} \mathrm{m}^{-3}$ for the 8-hr maximum $\mathrm{O}_{3}$ concentration (color scale) and the logarithm of the $\mathrm{VOCs} / \mathrm{NO}_{x}$ concentration ratio (contour lines) during the high $\mathrm{O}_{3}$ season (from April to September) in 2004 simulated by CALIOPE at a $4 \mathrm{~km} \times 4 \mathrm{~km}$ over the land domain (a) and the entire domain (b). In both cases, correlation between days exceeding the concentration value of $120 \mu \mathrm{g} \mathrm{m}^{-3}$ and the logarithm of the VOCs/NO ${ }_{x}$ concentration ratio is showed at the bottom-right. 
Table 1: Location and characteristics of selected RedESP stations (source: CEAM) for 2004 on an hourly basis. 68 stations were used to monitor $\mathrm{NO}_{2}, 45$ for $\mathrm{SO}_{2}, 82$ for $\mathrm{O}_{3}$, and 44 for PM10, respectively.

\begin{tabular}{|c|c|c|c|c|c|c|c|c|c|}
\hline & \multirow[b]{2}{*}{$\begin{array}{c}\text { Station } \\
\text { name }\end{array}$} & \multirow[b]{2}{*}{ Latitude $^{\mathrm{a}}$} & \multirow[b]{2}{*}{ Longitude $^{\mathrm{a}}$} & \multirow[b]{2}{*}{$\begin{array}{r}\text { Altitude } \\
(\mathrm{m})\end{array}$} & \multirow[b]{2}{*}{ Type $^{\text {b }}$} & \multicolumn{4}{|c|}{ Hourly concentration } \\
\hline & & & & & & $\mathrm{NO}_{2}$ & $\mathrm{SO}_{2}$ & $\mathrm{O}_{3}$ & $\mathrm{PM}_{10}$ \\
\hline 1 & Abanto & +43.322 & -3.073 & 75 & SI & $\mathrm{x}$ & $\mathrm{x}$ & $\mathrm{x}$ & $\mathrm{x}$ \\
\hline 2 & Acueducto & +40.950 & -4.116 & 1002 & UT & $\mathrm{x}$ & & $\mathrm{x}$ & $\mathrm{x}$ \\
\hline 3 & Agro & +38.242 & -0.683 & 44 & SI & $\mathrm{x}$ & $\mathrm{x}$ & $\mathrm{x}$ & \\
\hline 4 & Al.Guadaira & +37.342 & -5.833 & 68 & UB & $\mathrm{x}$ & & $\mathrm{x}$ & $\mathrm{x}$ \\
\hline 5 & Alagón & +41.763 & -1.143 & 235 & RT & $\mathrm{x}$ & $\mathrm{x}$ & $\mathrm{x}$ & \\
\hline 6 & Albacete & +38.981 & -1.957 & 686 & SB & $\mathrm{x}$ & $\mathrm{x}$ & $\mathrm{x}$ & $\mathrm{x}$ \\
\hline 7 & Alcobendas(R.) & +40.541 & -3.646 & 688 & UB & $\mathrm{x}$ & $\mathrm{x}$ & $\mathrm{x}$ & $\mathrm{x}$ \\
\hline 8 & Alcudial_Alc & +39.838 & +3.147 & 15 & $\mathrm{RB}$ & $\mathrm{x}$ & & $\mathrm{x}$ & \\
\hline 9 & Aljarafe & +37.340 & -6.043 & 68 & SB & $\mathrm{x}$ & $\mathrm{x}$ & $\mathrm{x}$ & $\mathrm{x}$ \\
\hline 10 & Aranjuez & +40.034 & -3.592 & 501 & UB & $\mathrm{x}$ & & $\mathrm{x}$ & $\mathrm{x}$ \\
\hline 11 & Av.Castilla & +43.538 & -5.646 & 7 & UT & $\mathrm{x}$ & $\mathrm{x}$ & $\mathrm{x}$ & $\mathrm{x}$ \\
\hline 12 & Azuqueca & +40.574 & -3.263 & 662 & SB & $\mathrm{x}$ & $\mathrm{x}$ & $\mathrm{x}$ & $\mathrm{x}$ \\
\hline 13 & Badajoz & +38.892 & -6.970 & 390 & SB & $\mathrm{x}$ & & $\mathrm{x}$ & $\mathrm{x}$ \\
\hline 14 & Barcarrota & +38.476 & -6.923 & 393 & $\mathrm{RB}$ & $\mathrm{x}$ & $\mathrm{x}$ & $\mathrm{x}$ & \\
\hline 15 & Basauri & +43.240 & -2.881 & 125 & UI & $\mathrm{x}$ & $\mathrm{x}$ & $\mathrm{x}$ & $\mathrm{x}$ \\
\hline 16 & Beasain & +43.048 & -2.191 & 153 & ST & $\mathrm{x}$ & & $\mathrm{x}$ & $\mathrm{x}$ \\
\hline 17 & Buitrago & +40.979 & -3.622 & 1024 & $\mathrm{RB}$ & & & $\mathrm{x}$ & \\
\hline 18 & Bujaralo & +41.505 & -0.152 & 327 & RT & $\mathrm{x}$ & & $\mathrm{x}$ & \\
\hline 19 & C.T. Compos 1 & +42.626 & -6.521 & 720 & RI & $\mathrm{x}$ & & $\mathrm{x}$ & $\mathrm{x}$ \\
\hline 20 & C.T. Guardo2 & +42.704 & -4.827 & 1065 & RI & & & $\mathrm{x}$ & \\
\hline 21 & Cabo de Creus & +42.319 & +3.316 & 23 & $\mathrm{RB}$ & $\mathrm{x}$ & $\mathrm{x}$ & $\mathrm{x}$ & \\
\hline 22 & Cáceres & +39.482 & -6.357 & 389 & ST & $\mathrm{x}$ & & $\mathrm{x}$ & $\mathrm{x}$ \\
\hline 23 & Campisábalos & +41.281 & -3.143 & 1360 & $\mathrm{RB}$ & $\mathrm{x}$ & $\mathrm{x}$ & $\mathrm{x}$ & \\
\hline 24 & Cangas & +43.181 & -6.550 & 330 & SI & $\mathrm{x}$ & $\mathrm{x}$ & $\mathrm{x}$ & $\mathrm{x}$ \\
\hline 25 & Casa Campo & +40.420 & -3.750 & 645 & SB & $\mathrm{x}$ & & $\mathrm{x}$ & $\mathrm{x}$ \\
\hline 26 & Cast. Bellver & +39.564 & +2.623 & 117 & SB & $\mathrm{x}$ & $\mathrm{x}$ & $\mathrm{x}$ & $\mathrm{x}$ \\
\hline 27 & Castellón & +39.983 & -0.045 & 28 & UT & $\mathrm{x}$ & $\mathrm{x}$ & $\mathrm{x}$ & $\mathrm{x}$ \\
\hline 28 & Cementerio & +41.674 & -4.697 & 695 & SI & $\mathrm{x}$ & & $\mathrm{x}$ & \\
\hline 29 & Centro & +37.389 & -5.992 & 19 & UB & & & $\mathrm{x}$ & \\
\hline 30 & Colmenar & +40.665 & -3.774 & 905 & UB & $\mathrm{x}$ & & $\mathrm{x}$ & $\mathrm{x}$ \\
\hline 31 & CTCC-Arguedas & +42.225 & -1.667 & 490 & RI & $\mathrm{x}$ & $\mathrm{x}$ & $\mathrm{x}$ & $\mathrm{x}$ \\
\hline 32 & Chapinería & +40.378 & -4.205 & 675 & $\mathrm{RB}$ & $\mathrm{x}$ & & $\mathrm{x}$ & $\mathrm{x}$ \\
\hline 33 & Doñana & +37.285 & -6.440 & 20 & $\mathrm{RB}$ & $\mathrm{x}$ & & $\mathrm{x}$ & $\mathrm{x}$ \\
\hline 34 & E2 Alcornocales & +36.234 & -5.540 & 189 & $\mathrm{RB}$ & & & $\mathrm{x}$ & \\
\hline 35 & Eixample & +41.386 & +2.154 & 12 & UT & $\mathrm{x}$ & $\mathrm{x}$ & $\mathrm{x}$ & \\
\hline 36 & El Arenosillo & +37.088 & -6.705 & 37 & $\mathrm{RB}$ & & & $\mathrm{x}$ & \\
\hline 37 & Els Torm & +41.395 & +0.721 & 470 & $\mathrm{RB}$ & $\mathrm{x}$ & $\mathrm{x}$ & $\mathrm{x}$ & \\
\hline 38 & Esc.Naval & +42.395 & -8.708 & 20 & SI & & $\mathrm{x}$ & $\mathrm{x}$ & \\
\hline 39 & Escullera & +41.353 & +2.177 & 16 & SI & & & $\mathrm{x}$ & \\
\hline 40 & Estacion & +40.657 & -4.690 & 1150 & UT & $\mathrm{x}$ & & $\mathrm{x}$ & $\mathrm{x}$ \\
\hline 41 & Grao & +39.984 & +0.009 & 10 & SI & $\mathrm{x}$ & $\mathrm{x}$ & $\mathrm{x}$ & \\
\hline 42 & Guadarra & +40.679 & -4.105 & 1025 & $\mathrm{RB}$ & & & $\mathrm{x}$ & \\
\hline 43 & Guarnizo & +43.404 & -3.842 & 16 & SI & $\mathrm{x}$ & $\mathrm{x}$ & $\mathrm{x}$ & $\mathrm{x}$ \\
\hline 44 & Huesca & +42.136 & -0.404 & 488 & UB & & & $\mathrm{x}$ & \\
\hline 45 & Instituto & +42.792 & -4.847 & 1120 & UI & $\mathrm{x}$ & $\mathrm{x}$ & $\mathrm{x}$ & $\mathrm{x}$ \\
\hline 46 & Izkiz & +42.653 & -2.501 & 810 & $\mathrm{RB}$ & $\mathrm{x}$ & $\mathrm{x}$ & $\mathrm{x}$ & $\mathrm{x}$ \\
\hline 47 & La Aljorra & +37.694 & -1.068 & 80 & SI & $\mathrm{x}$ & & $\mathrm{x}$ & $\mathrm{x}$ \\
\hline 48 & Louseiras & +43.536 & -7.740 & 540 & RI & $\mathrm{x}$ & $\mathrm{x}$ & $\mathrm{x}$ & $\mathrm{x}$ \\
\hline 49 & Majadahonda & +40.446 & -3.868 & 730 & SB & $\mathrm{x}$ & & $\mathrm{x}$ & $\mathrm{x}$ \\
\hline 50 & Manresa & +41.731 & 1.826 & 238 & UT & $\mathrm{x}$ & & $\mathrm{x}$ & \\
\hline 51 & Mas Matas & +40.841 & -0.249 & 510 & RI & $\mathrm{x}$ & $\mathrm{x}$ & $\mathrm{x}$ & $\mathrm{x}$ \\
\hline
\end{tabular}




\begin{tabular}{|c|c|c|c|c|c|c|c|c|c|}
\hline & \multirow[b]{2}{*}{$\begin{array}{c}\text { Station } \\
\text { name }\end{array}$} & \multirow{2}{*}{ Latitude $^{\mathrm{a}}$} & \multirow{2}{*}{ Longitude $^{\mathrm{a}}$} & \multirow[b]{2}{*}{$\begin{array}{r}\text { Altitude } \\
(\mathrm{m})\end{array}$} & \multirow[b]{2}{*}{ Type $^{\mathrm{b}}$} & \multicolumn{4}{|c|}{ Hourly concentration } \\
\hline & & & & & & $\mathrm{NO}_{2}$ & $\mathrm{SO}_{2}$ & $\mathrm{O}_{3}$ & $\mathrm{PM}_{10}$ \\
\hline 52 & Mda. de Ebro1 & +42.682 & -2.918 & 471 & ST & & & $\mathrm{x}$ & \\
\hline 53 & Medina & +41.316 & -4.909 & 721 & SI & $\mathrm{x}$ & & $\mathrm{x}$ & $\mathrm{x}$ \\
\hline 54 & Monzón & +41.918 & +0.197 & 279 & RI & & & $\mathrm{x}$ & \\
\hline 55 & Morella & +40.636 & -0.093 & 1150 & RI & $\mathrm{x}$ & $\mathrm{x}$ & $\mathrm{x}$ & $\mathrm{x}$ \\
\hline 56 & Mundaka & +43.406 & -2.704 & 116 & RI & $\mathrm{x}$ & $\mathrm{x}$ & $\mathrm{x}$ & $\mathrm{x}$ \\
\hline 57 & Niembro & +43.439 & -4.850 & 134 & $\mathrm{RB}$ & $\mathrm{x}$ & $\mathrm{x}$ & $\mathrm{x}$ & \\
\hline 58 & O Saviñao & +42.635 & -7.705 & 506 & $\mathrm{RB}$ & $\mathrm{x}$ & $\mathrm{x}$ & $\mathrm{x}$ & \\
\hline 59 & P. Silla & +39.458 & -0.377 & 11 & UT & $\mathrm{x}$ & $\mathrm{x}$ & $\mathrm{x}$ & \\
\hline 60 & Pagoeta & +43.251 & -2.155 & 215 & $\mathrm{RB}$ & $\mathrm{x}$ & & $\mathrm{x}$ & $\mathrm{x}$ \\
\hline 61 & Pal. Deportes & +43.367 & -5.831 & 206 & ST & $\mathrm{x}$ & $\mathrm{x}$ & $\mathrm{x}$ & $\mathrm{x}$ \\
\hline 62 & Pardines & +42.312 & +2.214 & 1224 & $\mathrm{RB}$ & & $\mathrm{x}$ & $\mathrm{x}$ & \\
\hline 63 & Penausende & +41.289 & -5.867 & 985 & $\mathrm{RB}$ & $\mathrm{x}$ & $\mathrm{x}$ & $\mathrm{x}$ & \\
\hline 64 & Peneta & +40.013 & -0.058 & 106 & SI & $\mathrm{x}$ & $\mathrm{x}$ & $\mathrm{x}$ & \\
\hline 65 & Ps. Martiricos & +36.729 & -4.427 & 4 & UT & $\mathrm{x}$ & & $\mathrm{x}$ & $\mathrm{x}$ \\
\hline 66 & Pte. Regeral & +41.654 & -4.735 & 691 & UI & $\mathrm{x}$ & $\mathrm{x}$ & $\mathrm{x}$ & $\mathrm{x}$ \\
\hline 67 & Puertollano & +38.683 & -4.089 & 670 & SI & $\mathrm{x}$ & $\mathrm{x}$ & $\mathrm{x}$ & $\mathrm{x}$ \\
\hline 68 & Recoletos & +40.423 & -3.692 & 648 & UT & $\mathrm{x}$ & $\mathrm{x}$ & $\mathrm{x}$ & $\mathrm{x}$ \\
\hline 69 & Reinosa & +43.001 & -4.136 & 851 & UB & $\mathrm{x}$ & $\mathrm{x}$ & $\mathrm{x}$ & $\mathrm{x}$ \\
\hline 70 & Reus & +41.151 & +1.120 & 103 & ST & $\mathrm{x}$ & $\mathrm{x}$ & $\mathrm{x}$ & \\
\hline 71 & Risco Llano & +39.523 & -4.353 & 1241 & $\mathrm{RB}$ & $\mathrm{x}$ & $\mathrm{x}$ & $\mathrm{x}$ & \\
\hline 72 & Roger Flor & +41.651 & -0.917 & 212 & UT & $\mathrm{x}$ & & $\mathrm{x}$ & $\mathrm{x}$ \\
\hline 73 & S. Cugat & +41.481 & +2.090 & 113 & UT & $\mathrm{x}$ & $\mathrm{x}$ & $\mathrm{x}$ & \\
\hline 74 & Salamanca2 & +40.965 & -5.656 & 797 & UI & $\mathrm{x}$ & $\mathrm{x}$ & $\mathrm{x}$ & \\
\hline 75 & Sierra Norte & +37.996 & -5.666 & 569 & $\mathrm{RB}$ & $\mathrm{x}$ & & $\mathrm{x}$ & $\mathrm{x}$ \\
\hline 76 & Sort & +42.407 & +1.130 & 692 & RT & & $\mathrm{x}$ & $\mathrm{x}$ & \\
\hline 77 & Teruel & +40.336 & -1.107 & 915 & UB & & & $\mathrm{x}$ & \\
\hline 78 & Toledo & +39.867 & -4.021 & 500 & SB & $\mathrm{x}$ & & $\mathrm{x}$ & $\mathrm{x}$ \\
\hline 79 & Verge & +38.707 & -0.467 & 534 & UT & $\mathrm{x}$ & $\mathrm{x}$ & $\mathrm{x}$ & \\
\hline 80 & Víznar & +37.237 & -3.534 & 1230 & $\mathrm{RB}$ & $\mathrm{x}$ & $\mathrm{x}$ & $\mathrm{x}$ & \\
\hline 81 & Zarra & +39.086 & -1.102 & 885 & $\mathrm{RB}$ & $\mathrm{x}$ & $\mathrm{x}$ & $\mathrm{x}$ & \\
\hline 82 & Zorita & +40.734 & -0.169 & 619 & RB & $\mathrm{x}$ & $\mathrm{x}$ & $\mathrm{x}$ & $\mathrm{x}$ \\
\hline
\end{tabular}

A positive value indicates northern latitudes or eastern longitudes. A negative value indicates southern latitudes or western longitudes.

${ }^{\mathrm{b}}$ U: Urban; S: Suburban; R: Rural; B: Background; I: Industrial; T: Traffic.

See Garber et al. (2002). 
Table 2: Annual statistics obtained with CALIOPE over Spain for 2004 at the RedESP stations. The calculated statistics are: measured mean $\left(\mu \mathrm{g} \mathrm{m}^{-3}\right)$, modeled mean $\left(\mu \mathrm{g} \mathrm{m}^{-3}\right)$, correlation coefficient $(\mathrm{r})$, Root Mean Square Error (RMSE, $\mu \mathrm{g} \mathrm{m}^{-3}$ ), Mean Fractional Bias (MFB, \%) and Error (MFE, \%). All metrics are calculated without cut-off value.

\begin{tabular}{llccccccc}
\hline Pollutant & Category & $\begin{array}{c}\text { Number of } \\
\text { stations }\end{array}$ & $\begin{array}{c}\text { Measured } \\
\text { mean }\end{array}$ & $\begin{array}{c}\text { Modeled } \\
\text { mean }\end{array}$ & $r$ & RMSE & MFB & MFE \\
\hline $\mathrm{NO}_{2}$ & All & 68 & 21.6 & 9.6 & 0.53 & 23.3 & -81.1 & 98.8 \\
hourly & Rural & 25 & 7.6 & 3.3 & 0.51 & 7.6 & -79.7 & 95.6 \\
& Suburban & 22 & 23.2 & 11.7 & 0.39 & 23.1 & -66.7 & 93.6 \\
& Urban & 21 & 36.5 & 14.8 & 0.47 & 33.6 & -97.7 & 107.9 \\
$\mathrm{SO}_{2}$ & All & 45 & 7.2 & 6.1 & 0.19 & 18.7 & -33.1 & 97.8 \\
hourly & Rural & 18 & 4.4 & 3.3 & 0.28 & 14.0 & -29.9 & 94.1 \\
& Suburban & 14 & 9.1 & 9.9 & 0.14 & 26.0 & -23.8 & 95.5 \\
& Urban & 13 & 9.3 & 6.0 & 0.14 & 15.1 & -47.1 & 105.4 \\
& & & & & & & & \\
PM10 & All & 44 & 29.6 & 7.5 & 0.38 & 33.4 & -111.8 & 119.8 \\
hourly & Rural & 12 & 19.6 & 5.9 & 0.43 & 20.4 & -96.0 & 110.4 \\
& Suburban & 17 & 35.0 & 8.0 & 0.36 & 39.7 & -118.6 & 123.6 \\
& Urban & 15 & 31.8 & 8.1 & 0.36 & 33.8 & -116.3 & 122.9 \\
\hline
\end{tabular}


Table 3: Annual statistics for $\mathrm{O}_{3}$ (hourly and daily peaks) obtained with CALIOPE over Spain for 2004 at the RedESP stations. The calculated statistics are: measured mean $\left(\mu \mathrm{g} \mathrm{m}^{-3}\right)$, modeled mean $(\mu \mathrm{g}$ $\mathrm{m}^{-3}$ ), correlation coefficient ( $\mathrm{r}$ ), Root Mean Square Error (RMSE, $\mu \mathrm{g} \mathrm{m}^{-3}$ ), Mean Fractional Bias (MFB, $\%$ ) and Error (MFE; \%), Mean Normalized Bias Error (MNBE, \%) and Gross Error (MNGE; \%). All metrics, except for $r$, are calculated with a $80 \mathrm{\mu g} \mathrm{m}^{-3}$ cut-off value (see US-EPA, 1991; Russell and Dennis, 2000).

\begin{tabular}{llccccccccc}
\hline Pollutant & Category & $\begin{array}{c}\text { Number } \\
\text { of } \\
\text { stations }\end{array}$ & $\begin{array}{c}\text { Measured } \\
\text { mean }\end{array}$ & $\begin{array}{c}\text { Modeled } \\
\text { mean }\end{array}$ & $r$ & RMSE & MFB & MFE & MNBE & MNGE \\
\hline $\mathrm{O}_{3}$ & All & 82 & 57.4 & 71.0 & 0.57 & 24.1 & -9.3 & 21.2 & -6.0 & 19.2 \\
hourly & Rural & 33 & 70.1 & 76.2 & 0.51 & 24.1 & -11.2 & 21.8 & -7.7 & 19.5 \\
& Suburban & 25 & 51.7 & 67.5 & 0.56 & 24.7 & -8.7 & 20.7 & -5.4 & 18.9 \\
& Urban & 24 & 45.4 & 67.4 & 0.60 & 23.4 & -4.2 & 19.8 & -1.2 & 18.9 \\
& & & & & & & & & & \\
$\mathrm{O}_{3}$ & All & 82 & 86.1 & 85.5 & 0.64 & 25.9 & -9.8 & 21.2 & -6.6 & 19.5 \\
peaks & Rural & 33 & 93.8 & 86.9 & 0.67 & 24.8 & -12.9 & 21.3 & -9.7 & 19.0 \\
& Suburban & 25 & 84.7 & 84.1 & 0.65 & 27.9 & -9.0 & 21.5 & -5.7 & 19.9 \\
& Urban & 24 & 76.6 & 85.0 & 0.63 & 25.8 & -4.2 & 20.7 & -1.0 & 20.0 \\
\hline
\end{tabular}


Table 1: Location and characteristics of selected RedESP stations (source: CEAM) for 2004 on an hourly basis. 68 stations were used to monitor $\mathrm{NO}_{2}, 45$ for $\mathrm{SO}_{2}, 82$ for $\mathrm{O}_{3}$, and 44 for $\mathrm{PM} 10$, respectively.

\begin{tabular}{|c|c|c|c|c|c|c|c|c|c|}
\hline & \multirow[b]{2}{*}{$\begin{array}{c}\text { Station } \\
\text { name }\end{array}$} & \multirow[b]{2}{*}{ Latitude $^{\mathrm{a}}$} & \multirow[b]{2}{*}{ Longitude $^{\mathrm{a}}$} & \multirow[b]{2}{*}{$\begin{array}{l}\text { Altitude } \\
(\mathrm{m})\end{array}$} & \multirow[b]{2}{*}{ Type $^{\text {b }}$} & \multicolumn{4}{|c|}{ Hourly concentration } \\
\hline & & & & & & $\mathrm{NO}_{2}$ & $\mathrm{SO}_{2}$ & $\mathrm{O}_{3}$ & $\mathrm{PM}_{10}$ \\
\hline 1 & Abanto & +43.322 & -3.073 & 75 & SI & $\mathrm{x}$ & $\mathrm{x}$ & $\mathrm{x}$ & $\mathrm{x}$ \\
\hline 2 & Acueducto & +40.950 & -4.116 & 1002 & UT & $\mathrm{x}$ & & $\mathrm{x}$ & $\mathrm{x}$ \\
\hline 3 & Agro & +38.242 & -0.683 & 44 & SI & $\mathrm{x}$ & $\mathrm{x}$ & $\mathrm{x}$ & \\
\hline 4 & Al.Guadaira & +37.342 & -5.833 & 68 & UB & $\mathrm{x}$ & & $\mathrm{x}$ & $\mathrm{x}$ \\
\hline 5 & Alagón & +41.763 & -1.143 & 235 & RT & $\mathrm{x}$ & $\mathrm{x}$ & $\mathrm{x}$ & \\
\hline 6 & Albacete & +38.981 & -1.957 & 686 & SB & $\mathrm{x}$ & $\mathrm{x}$ & $\mathrm{x}$ & $\mathrm{x}$ \\
\hline 7 & Alcobendas(R.) & +40.541 & -3.646 & 688 & UB & $\mathrm{x}$ & $\mathrm{x}$ & $\mathrm{x}$ & $\mathrm{x}$ \\
\hline 8 & Alcudial_Alc & +39.838 & +3.147 & 15 & $\mathrm{RB}$ & $\mathrm{x}$ & & $\mathrm{x}$ & \\
\hline 9 & Aljarafe & +37.340 & -6.043 & 68 & SB & $\mathrm{x}$ & $\mathrm{x}$ & $\mathrm{x}$ & $\mathrm{x}$ \\
\hline 10 & Aranjuez & +40.034 & -3.592 & 501 & UB & $\mathrm{x}$ & & $\mathrm{x}$ & $\mathrm{x}$ \\
\hline 11 & Av.Castilla & +43.538 & -5.646 & 7 & UT & $\mathrm{x}$ & $\mathrm{x}$ & $\mathrm{x}$ & $\mathrm{x}$ \\
\hline 12 & Azuqueca & +40.574 & -3.263 & 662 & SB & $\mathrm{x}$ & $\mathrm{x}$ & $\mathrm{x}$ & $\mathrm{x}$ \\
\hline 13 & Badajoz & +38.892 & -6.970 & 390 & SB & $\mathrm{x}$ & & $\mathrm{x}$ & $\mathrm{x}$ \\
\hline 14 & Barcarrota & +38.476 & -6.923 & 393 & $\mathrm{RB}$ & $\mathrm{x}$ & $\mathrm{x}$ & $\mathrm{x}$ & \\
\hline 15 & Basauri & +43.240 & -2.881 & 125 & UI & $\mathrm{x}$ & $\mathrm{x}$ & $\mathrm{x}$ & $\mathrm{x}$ \\
\hline 16 & Beasain & +43.048 & -2.191 & 153 & ST & $\mathrm{x}$ & & $\mathrm{x}$ & $\mathrm{x}$ \\
\hline 17 & Buitrago & +40.979 & -3.622 & 1024 & $\mathrm{RB}$ & & & $\mathrm{x}$ & \\
\hline 18 & Bujaralo & +41.505 & -0.152 & 327 & RT & $\mathrm{x}$ & & $\mathrm{x}$ & \\
\hline 19 & C.T. Compos 1 & +42.626 & -6.521 & 720 & RI & $\mathrm{x}$ & & $\mathrm{x}$ & $\mathrm{x}$ \\
\hline 20 & C.T. Guardo2 & +42.704 & -4.827 & 1065 & RI & & & $\mathrm{x}$ & \\
\hline 21 & Cabo de Creus & +42.319 & +3.316 & 23 & $\mathrm{RB}$ & $\mathrm{x}$ & $\mathrm{x}$ & $\mathrm{x}$ & \\
\hline 22 & Cáceres & +39.482 & -6.357 & 389 & ST & $\mathrm{x}$ & & $\mathrm{x}$ & $\mathrm{x}$ \\
\hline 23 & Campisábalos & +41.281 & -3.143 & 1360 & $\mathrm{RB}$ & $\mathrm{x}$ & $\mathrm{x}$ & $\mathrm{x}$ & \\
\hline 24 & Cangas & +43.181 & -6.550 & 330 & SI & $\mathrm{x}$ & $\mathrm{x}$ & $\mathrm{x}$ & $\mathrm{x}$ \\
\hline 25 & Casa Campo & +40.420 & -3.750 & 645 & SB & $\mathrm{x}$ & & $\mathrm{x}$ & $\mathrm{x}$ \\
\hline 26 & Cast. Bellver & +39.564 & +2.623 & 117 & SB & $\mathrm{x}$ & $\mathrm{x}$ & $\mathrm{x}$ & $\mathrm{x}$ \\
\hline 27 & Castellón & +39.983 & -0.045 & 28 & UT & $\mathrm{x}$ & $\mathrm{x}$ & $\mathrm{x}$ & $\mathrm{x}$ \\
\hline 28 & Cementerio & +41.674 & -4.697 & 695 & SI & $\mathrm{x}$ & & $\mathrm{x}$ & \\
\hline 29 & Centro & +37.389 & -5.992 & 19 & UB & & & $\mathrm{x}$ & \\
\hline 30 & Colmenar & +40.665 & -3.774 & 905 & UB & $\mathrm{x}$ & & $\mathrm{x}$ & $\mathrm{x}$ \\
\hline 31 & CTCC-Arguedas & +42.225 & -1.667 & 490 & RI & $\mathrm{x}$ & $\mathrm{x}$ & $\mathrm{x}$ & $\mathrm{x}$ \\
\hline 32 & Chapinería & +40.378 & -4.205 & 675 & $\mathrm{RB}$ & $\mathrm{x}$ & & $\mathrm{x}$ & $\mathrm{x}$ \\
\hline 33 & Doñana & +37.285 & -6.440 & 20 & $\mathrm{RB}$ & $\mathrm{x}$ & & $\mathrm{x}$ & $\mathrm{x}$ \\
\hline 34 & E2 Alcornocales & +36.234 & -5.540 & 189 & $\mathrm{RB}$ & & & $\mathrm{x}$ & \\
\hline 35 & Eixample & +41.386 & +2.154 & 12 & UT & $\mathrm{x}$ & $\mathrm{x}$ & $\mathrm{x}$ & \\
\hline 36 & El Arenosillo & +37.088 & -6.705 & 37 & $\mathrm{RB}$ & & & $\mathrm{x}$ & \\
\hline 37 & Els Torm & +41.395 & +0.721 & 470 & $\mathrm{RB}$ & $\mathrm{x}$ & $\mathrm{x}$ & $\mathrm{x}$ & \\
\hline 38 & Esc.Naval & +42.395 & -8.708 & 20 & SI & & $\mathrm{x}$ & $\mathrm{x}$ & \\
\hline 39 & Escullera & +41.353 & +2.177 & 16 & SI & & & $\mathrm{x}$ & \\
\hline 40 & Estacion & +40.657 & -4.690 & 1150 & UT & $\mathrm{x}$ & & $\mathrm{x}$ & $\mathrm{x}$ \\
\hline 41 & Grao & +39.984 & +0.009 & 10 & SI & $\mathrm{x}$ & $\mathrm{x}$ & $\mathrm{x}$ & \\
\hline 42 & Guadarra & +40.679 & -4.105 & 1025 & $\mathrm{RB}$ & & & $\mathrm{x}$ & \\
\hline 43 & Guarnizo & +43.404 & -3.842 & 16 & SI & $\mathrm{x}$ & $\mathrm{x}$ & $\mathrm{x}$ & $\mathrm{x}$ \\
\hline 44 & Huesca & +42.136 & -0.404 & 488 & UB & & & $\mathrm{x}$ & \\
\hline 45 & Instituto & +42.792 & -4.847 & 1120 & UI & $\mathrm{x}$ & $\mathrm{x}$ & $\mathrm{x}$ & $\mathrm{x}$ \\
\hline 46 & Izkiz & +42.653 & -2.501 & 810 & RB & $\hat{x}$ & $\hat{x}$ & $\begin{array}{l}\hat{x} \\
\mathrm{x}\end{array}$ & $\hat{x}$ \\
\hline 47 & La Aljorra & +37.694 & -1.068 & 80 & SI & $\mathrm{x}$ & & $\mathrm{x}$ & $\mathrm{x}$ \\
\hline 48 & Louseiras & +43.536 & -7.740 & 540 & RI & $\mathrm{x}$ & $\mathrm{x}$ & $\mathrm{x}$ & $\mathrm{x}$ \\
\hline 49 & Majadahonda & +40.446 & -3.868 & 730 & SB & $\mathrm{x}$ & & $\mathrm{x}$ & $\mathrm{x}$ \\
\hline 50 & Manresa & +41.731 & 1.826 & 238 & UT & $\mathrm{x}$ & & $\mathrm{x}$ & \\
\hline 51 & Mas Matas & +40.841 & -0.249 & 510 & RI & $\mathrm{x}$ & $\mathrm{x}$ & $\mathrm{x}$ & $\mathrm{x}$ \\
\hline
\end{tabular}


Table 1: Continue

\begin{tabular}{|c|c|c|c|c|c|c|c|c|c|}
\hline & \multirow[b]{2}{*}{$\begin{array}{c}\text { Station } \\
\text { name }\end{array}$} & \multirow[b]{2}{*}{ Latitude $^{\mathrm{a}}$} & \multirow[b]{2}{*}{ Longitude $^{a}$} & \multirow[b]{2}{*}{$\begin{array}{r}\text { Altitude } \\
(\mathrm{m})\end{array}$} & \multirow[b]{2}{*}{ Type $^{\text {b }}$} & \multicolumn{4}{|c|}{ Hourly concentration } \\
\hline & & & & & & $\mathrm{NO}_{2}$ & $\mathrm{SO}_{2}$ & $\mathrm{O}_{3}$ & $\mathrm{PM}_{10}$ \\
\hline 52 & Mda. de Ebro1 & +42.682 & -2.918 & 471 & ST & & & $\mathrm{x}$ & \\
\hline 53 & Medina & +41.316 & -4.909 & 721 & SI & $\mathrm{x}$ & & $\mathrm{x}$ & $\mathrm{x}$ \\
\hline 54 & Monzón & +41.918 & +0.197 & 279 & RI & & & $\mathrm{x}$ & \\
\hline 55 & Morella & +40.636 & -0.093 & 1150 & RI & $\mathrm{x}$ & $\mathrm{x}$ & $\mathrm{x}$ & $\mathrm{x}$ \\
\hline 56 & Mundaka & +43.406 & -2.704 & 116 & RI & $\mathrm{x}$ & $\mathrm{x}$ & $\mathrm{x}$ & $\mathrm{x}$ \\
\hline 57 & Niembro & +43.439 & -4.850 & 134 & $\mathrm{RB}$ & $\mathrm{x}$ & $\mathrm{x}$ & $\mathrm{x}$ & \\
\hline 58 & O Saviñao & +42.635 & -7.705 & 506 & $\mathrm{RB}$ & $\mathrm{x}$ & $\mathrm{x}$ & $\mathrm{x}$ & \\
\hline 59 & P. Silla & +39.458 & -0.377 & 11 & UT & $\mathrm{x}$ & $\mathrm{x}$ & $\mathrm{x}$ & \\
\hline 60 & Pagoeta & +43.251 & -2.155 & 215 & $\mathrm{RB}$ & $\mathrm{x}$ & & $\mathrm{x}$ & $\mathrm{x}$ \\
\hline 61 & Pal. Deportes & +43.367 & -5.831 & 206 & ST & $\mathrm{x}$ & $\mathrm{x}$ & $\mathrm{x}$ & $\mathrm{x}$ \\
\hline 62 & Pardines & +42.312 & +2.214 & 1224 & $\mathrm{RB}$ & & $\mathrm{x}$ & $\mathrm{x}$ & \\
\hline 63 & Penausende & +41.289 & -5.867 & 985 & $\mathrm{RB}$ & $\mathrm{x}$ & $\mathrm{x}$ & $\mathrm{x}$ & \\
\hline 64 & Peneta & +40.013 & -0.058 & 106 & SI & $\mathrm{x}$ & $\mathrm{x}$ & $\mathrm{x}$ & \\
\hline 65 & Ps. Martiricos & +36.729 & -4.427 & 4 & UT & $\mathrm{x}$ & & $\mathrm{x}$ & $\mathrm{x}$ \\
\hline 66 & Pte. Regeral & +41.654 & -4.735 & 691 & UI & $\mathrm{x}$ & $\mathrm{x}$ & $\mathrm{x}$ & $\mathrm{x}$ \\
\hline 67 & Puertollano & +38.683 & -4.089 & 670 & SI & $\mathrm{x}$ & $\mathrm{x}$ & $\mathrm{x}$ & $\mathrm{x}$ \\
\hline 68 & Recoletos & +40.423 & -3.692 & 648 & UT & $\mathrm{x}$ & $\mathrm{x}$ & $\mathrm{x}$ & $\mathrm{x}$ \\
\hline 69 & Reinosa & +43.001 & -4.136 & 851 & UB & $\mathrm{x}$ & $\mathrm{x}$ & $\mathrm{x}$ & $\mathrm{x}$ \\
\hline 70 & Reus & +41.151 & +1.120 & 103 & ST & $\mathrm{x}$ & $\mathrm{x}$ & $\mathrm{x}$ & \\
\hline 71 & Risco Llano & +39.523 & -4.353 & 1241 & $\mathrm{RB}$ & $\mathrm{x}$ & $\mathrm{x}$ & $\mathrm{x}$ & \\
\hline 72 & Roger Flor & +41.651 & -0.917 & 212 & UT & $\mathrm{x}$ & & $\mathrm{x}$ & $\mathrm{x}$ \\
\hline 73 & S. Cugat & +41.481 & +2.090 & 113 & UT & $\mathrm{x}$ & $\mathrm{x}$ & $\mathrm{x}$ & \\
\hline 74 & Salamanca2 & +40.965 & -5.656 & 797 & UI & $\mathrm{x}$ & $\mathrm{x}$ & $\mathrm{x}$ & \\
\hline 75 & Sierra Norte & +37.996 & -5.666 & 569 & $\mathrm{RB}$ & $\mathrm{x}$ & & $\mathrm{x}$ & $\mathrm{x}$ \\
\hline 76 & Sort & +42.407 & +1.130 & 692 & $\mathrm{RT}$ & & $\mathrm{x}$ & $\mathrm{x}$ & \\
\hline 77 & Teruel & +40.336 & -1.107 & 915 & UB & & & $\mathrm{x}$ & \\
\hline 78 & Toledo & +39.867 & -4.021 & 500 & SB & $\mathrm{x}$ & & $\mathrm{x}$ & $\mathrm{x}$ \\
\hline 79 & Verge & +38.707 & -0.467 & 534 & UT & $\mathrm{x}$ & $\mathrm{x}$ & $\mathrm{x}$ & \\
\hline 80 & Víznar & +37.237 & -3.534 & 1230 & RB & $\mathrm{x}$ & $\mathrm{x}$ & $\mathrm{x}$ & \\
\hline 81 & Zarra & +39.086 & -1.102 & 885 & $\mathrm{RB}$ & $\mathrm{x}$ & $\mathrm{x}$ & $\mathrm{x}$ & \\
\hline 82 & Zorita & +40.734 & -0.169 & 619 & $\mathrm{RB}$ & $\mathrm{x}$ & $\mathrm{x}$ & $\mathrm{x}$ & $\mathrm{x}$ \\
\hline
\end{tabular}

${ }^{a}$ A positive value indicates northern latitudes or eastern longitudes. A negative value indicates southern latitudes or western longitudes.

${ }^{\mathrm{b}}$ U: Urban; S: Suburban; R: Rural; B: Background; I: Industrial; T: Traffic. See Garber et al. (2002). 

Table 2: Annual statistics obtained with CALIOPE over Spain for 2004 at the RedESP stations. The calculated statistics are: measured mean $\left(\mu \mathrm{g} \mathrm{m}^{-3}\right)$, modeled mean $\left(\mu \mathrm{g} \mathrm{m}^{-3}\right)$, correlation coefficient $(\mathrm{r})$, Root Mean Square Error (RMSE, $\mu \mathrm{g} \mathrm{m} \mathrm{m}^{-}$ ${ }^{3}$ ), Mean Fractional Bias (MFB, \%) and Error (MFE, \%). All metrics are calculated without cut-off value.

\begin{tabular}{llccccccc}
\hline Pollutant & Category & $\begin{array}{c}\text { Number of } \\
\text { stations }\end{array}$ & $\begin{array}{c}\text { Measured } \\
\text { mean }\end{array}$ & $\begin{array}{c}\text { Modeled } \\
\text { mean }\end{array}$ & $\mathrm{r}$ & RMSE & MFB & MFE \\
\hline $\mathrm{NO}_{2}$ & All & 68 & 21.6 & 9.6 & 0.53 & 23.3 & -81.1 & 98.8 \\
hourly & Rural & 25 & 7.6 & 3.3 & 0.51 & 7.6 & -79.7 & 95.6 \\
& Suburban & 22 & 23.2 & 11.7 & 0.39 & 23.1 & -66.7 & 93.6 \\
& Urban & 21 & 36.5 & 14.8 & 0.47 & 33.6 & -97.7 & 107.9 \\
$\mathrm{SO}_{2}$ & All & 45 & 7.2 & 6.1 & 0.19 & 18.7 & -33.1 & 97.8 \\
hourly & Rural & 18 & 4.4 & 3.3 & 0.28 & 14.0 & -29.9 & 94.1 \\
& Suburban & 14 & 9.1 & 9.9 & 0.14 & 26.0 & -23.8 & 95.5 \\
& Urban & 13 & 9.3 & 6.0 & 0.14 & 15.1 & -47.1 & 105.4 \\
PM10 & All & 44 & 29.6 & 7.5 & 0.38 & 33.4 & -111.8 & 119.8 \\
hourly & Rural & 12 & 19.6 & 5.9 & 0.43 & 20.4 & -96.0 & 110.4 \\
& Suburban & 17 & 35.0 & 8.0 & 0.36 & 39.7 & -118.6 & 123.6 \\
& Urban & 15 & 31.8 & 8.1 & 0.36 & 33.8 & -116.3 & 122.9 \\
\hline
\end{tabular}




\section{Table 3}

\section{Click here to download Table: Table3.doc}

Table 3: Annual statistics for $\mathrm{O}_{3}$ (hourly and daily peaks) obtained with CALIOPE over Spain for 2004 at the RedESP stations. The calculated statistics are: measured mean $\left(\mu \mathrm{g} \mathrm{m}^{-3}\right)$, modeled mean $(\mu \mathrm{g}$ $\mathrm{m}^{-3}$ ), correlation coefficient $\left(\mathrm{r}\right.$ ), Root Mean Square Error (RMSE, $\mu \mathrm{g} \mathrm{m}^{-3}$ ), Mean Fractional Bias (MFB, $\%$ ) and Error (MFE; \%), Mean Normalized Bias Error (MNBE, \%) and Gross Error (MNGE; \%). All metrics, except for $r$, are calculated with a $80 \mathrm{\mu g} \mathrm{m}^{-3}$ cut-off value (see US-EPA, 1991; Russell and Dennis, 2000).

\begin{tabular}{llccccccccc}
\hline Pollutant & Category & $\begin{array}{c}\text { Number } \\
\text { of } \\
\text { stations }\end{array}$ & $\begin{array}{c}\text { Measured } \\
\text { mean }\end{array}$ & $\begin{array}{c}\text { Modeled } \\
\text { mean }\end{array}$ & $r$ & RMSE & MFB & MFE & MNBE & MNGE \\
\hline $\mathrm{O}_{3}$ & All & 82 & 57.4 & 71.0 & 0.57 & 24.1 & -9.3 & 21.2 & -6.0 & 19.2 \\
hourly & Rural & 33 & 70.1 & 76.2 & 0.51 & 24.1 & -11.2 & 21.8 & -7.7 & 19.5 \\
& Suburban & 25 & 51.7 & 67.5 & 0.56 & 24.7 & -8.7 & 20.7 & -5.4 & 18.9 \\
& Urban & 24 & 45.4 & 67.4 & 0.60 & 23.4 & -4.2 & 19.8 & -1.2 & 18.9 \\
& & & & & & & & & & \\
$\mathrm{O}_{3}$ & All & 82 & 86.1 & 85.5 & 0.64 & 25.9 & -9.8 & 21.2 & -6.6 & 19.5 \\
peaks & Rural & 33 & 93.8 & 86.9 & 0.67 & 24.8 & -12.9 & 21.3 & -9.7 & 19.0 \\
& Suburban & 25 & 84.7 & 84.1 & 0.65 & 27.9 & -9.0 & 21.5 & -5.7 & 19.9 \\
& Urban & 24 & 76.6 & 85.0 & 0.63 & 25.8 & -4.2 & 20.7 & -1.0 & 20.0 \\
\hline
\end{tabular}




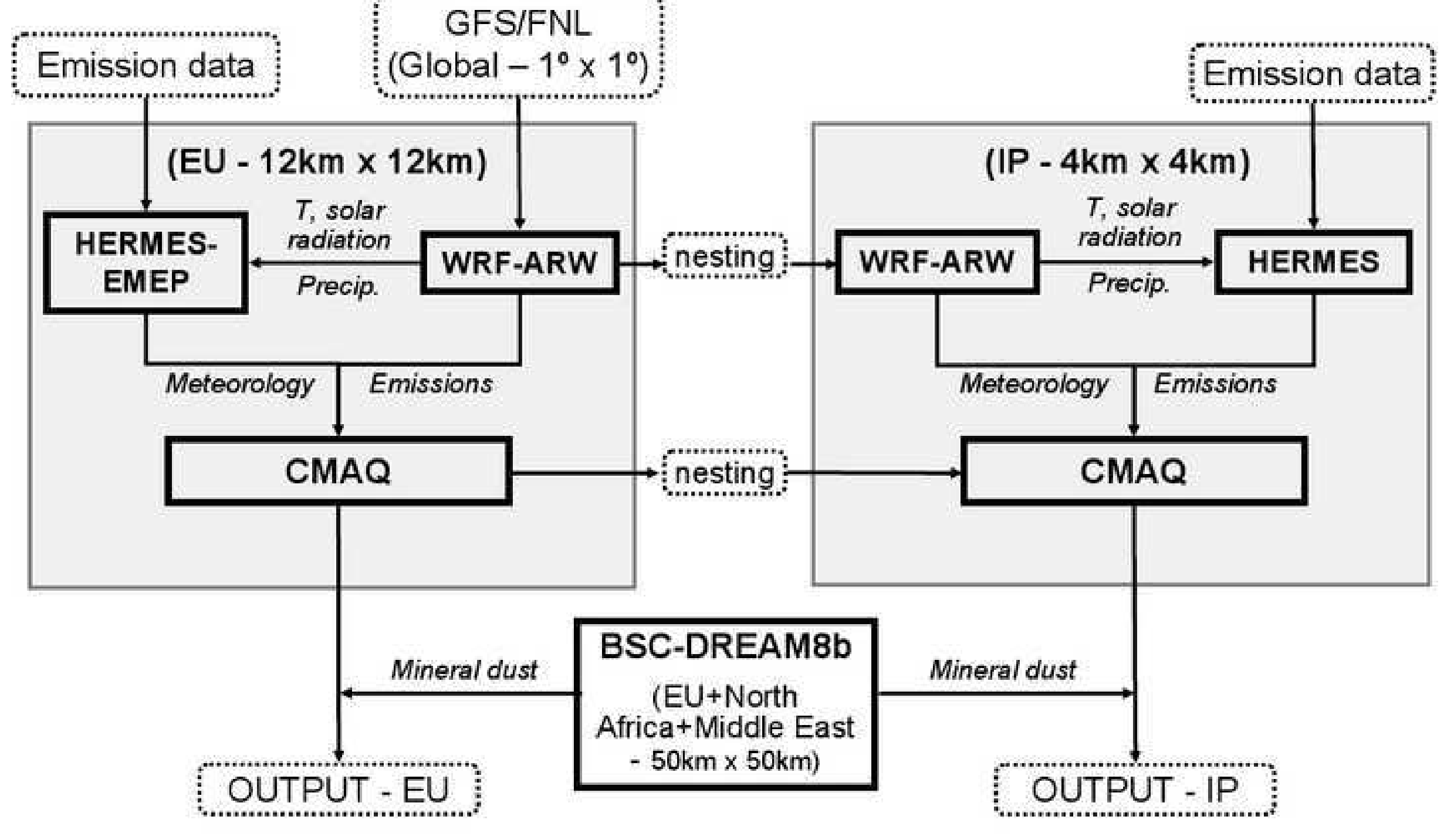




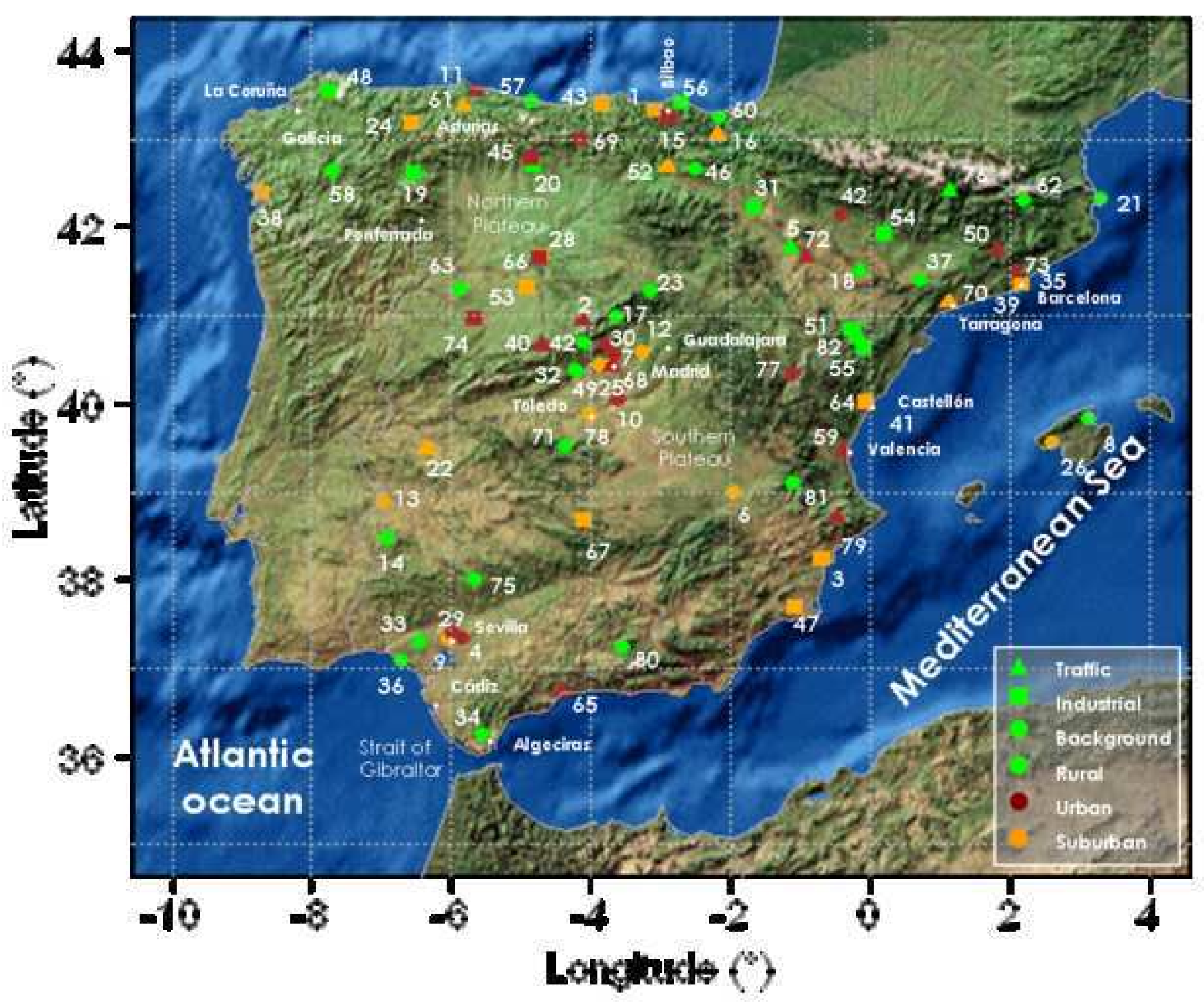



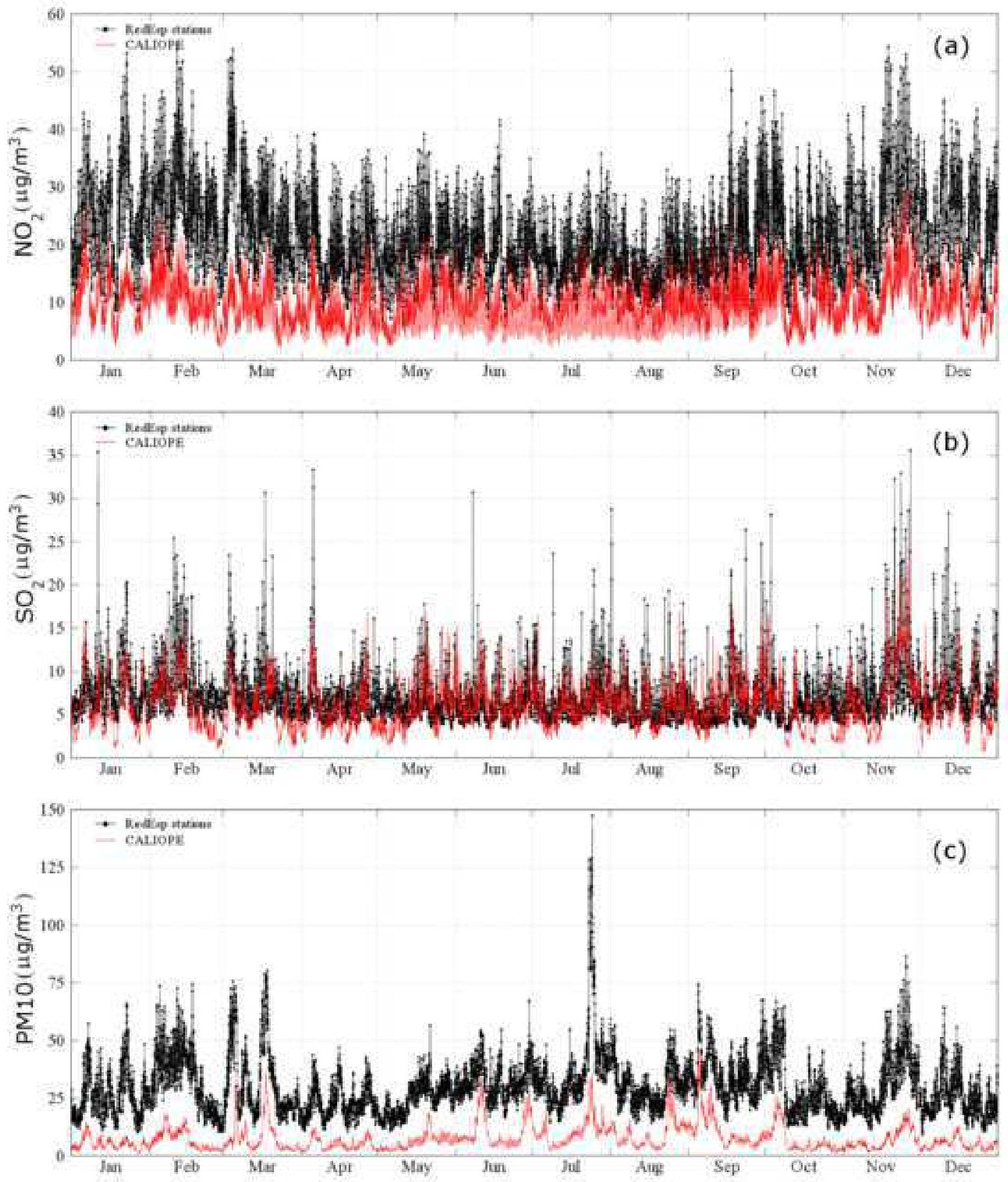

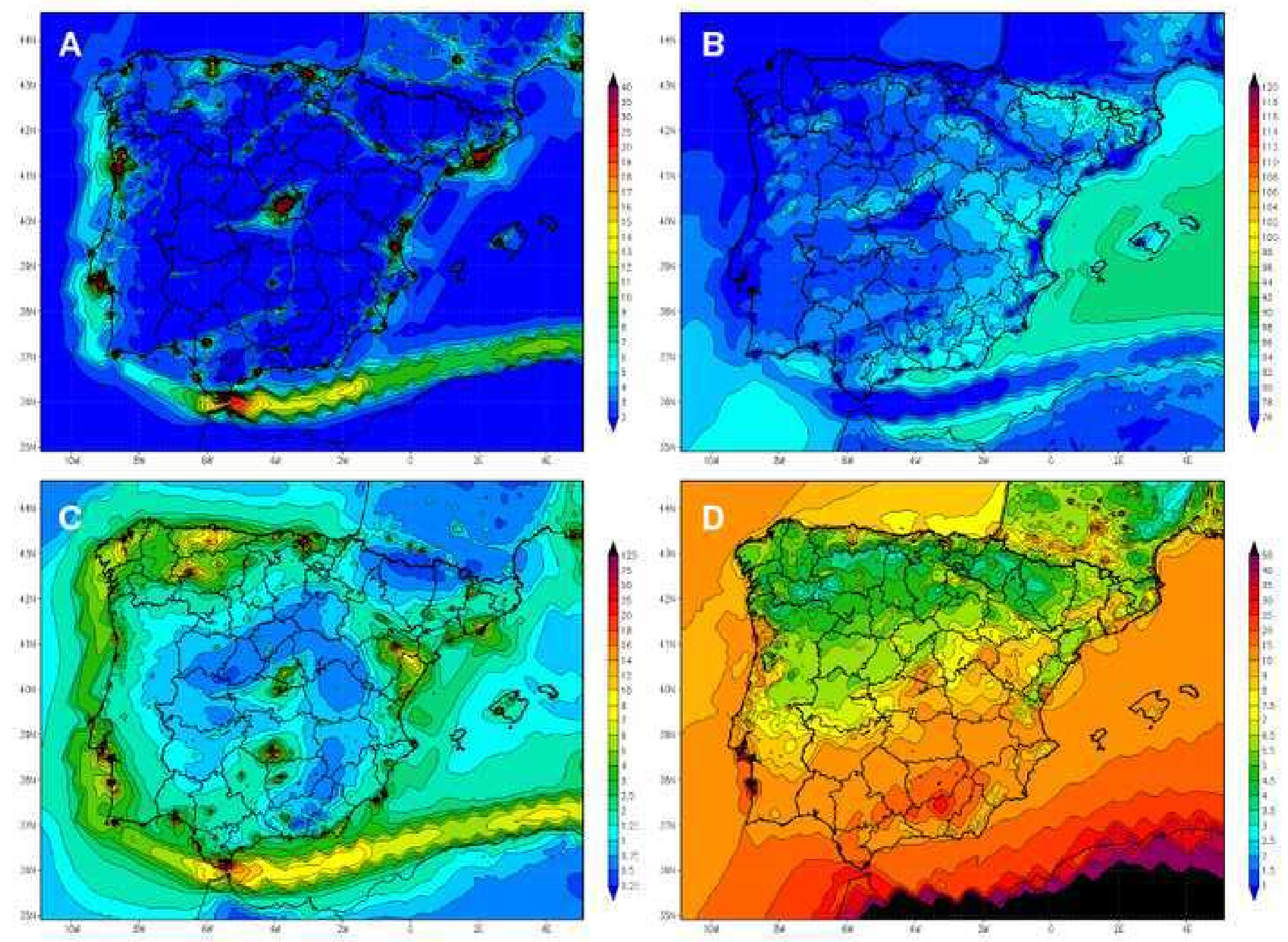


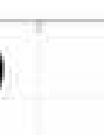

110

90

70

${ }_{30}^{90}$

$10 \mathrm{~J}$

Jan

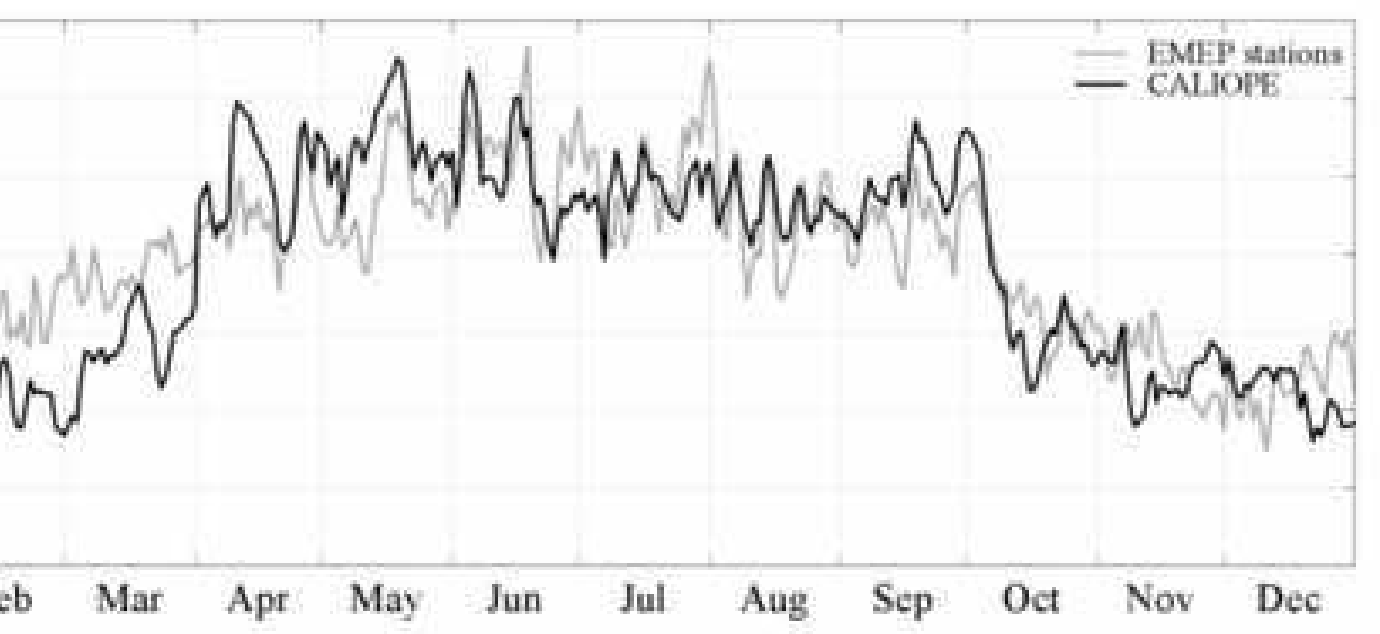

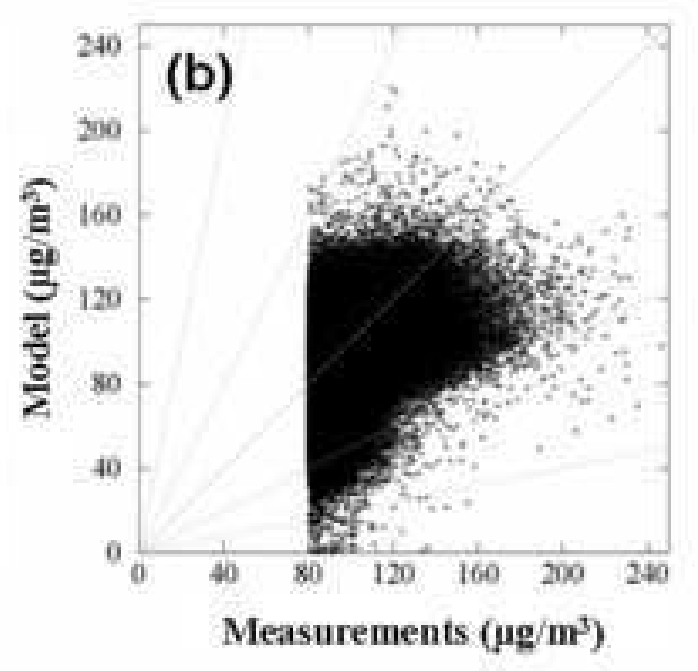



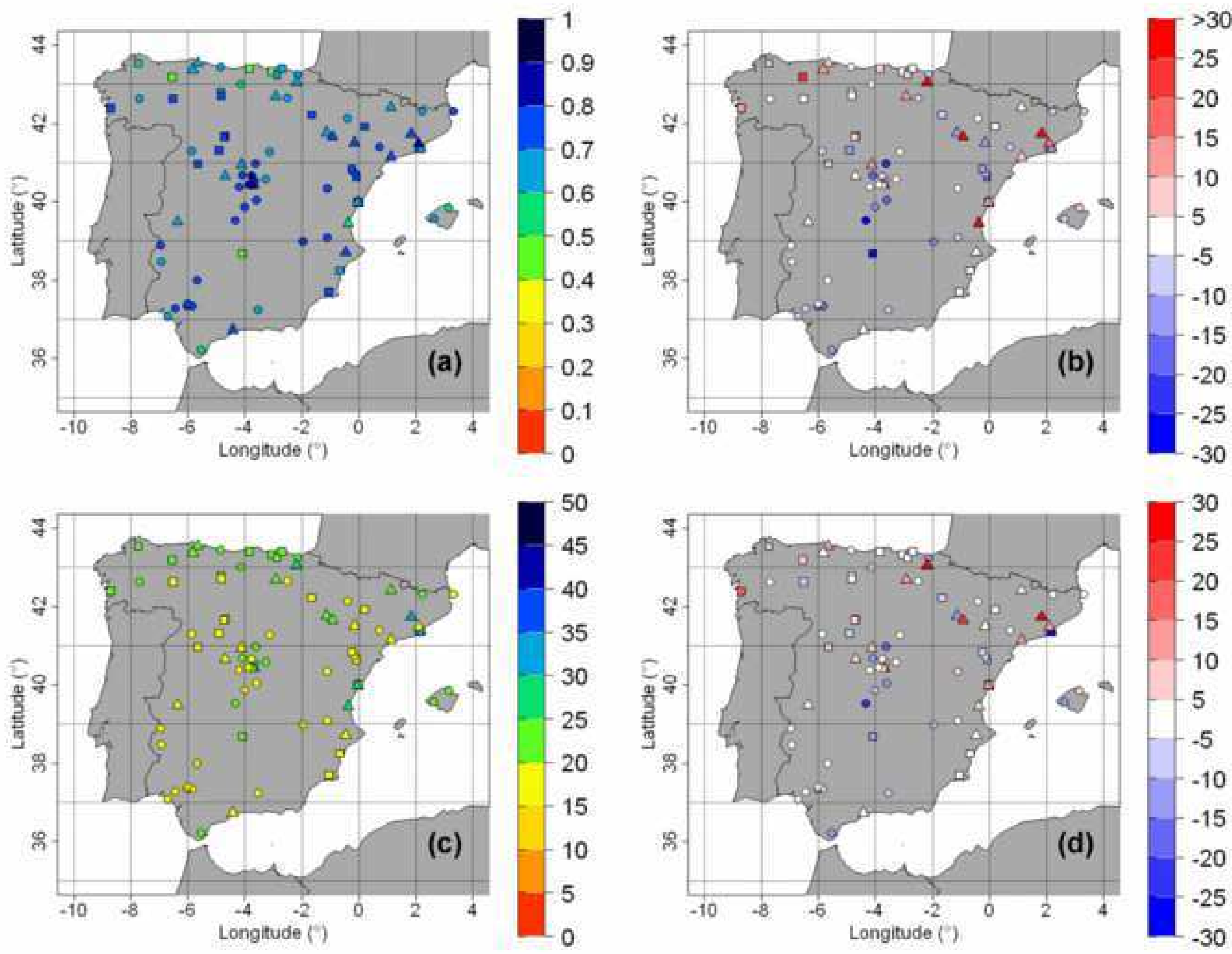


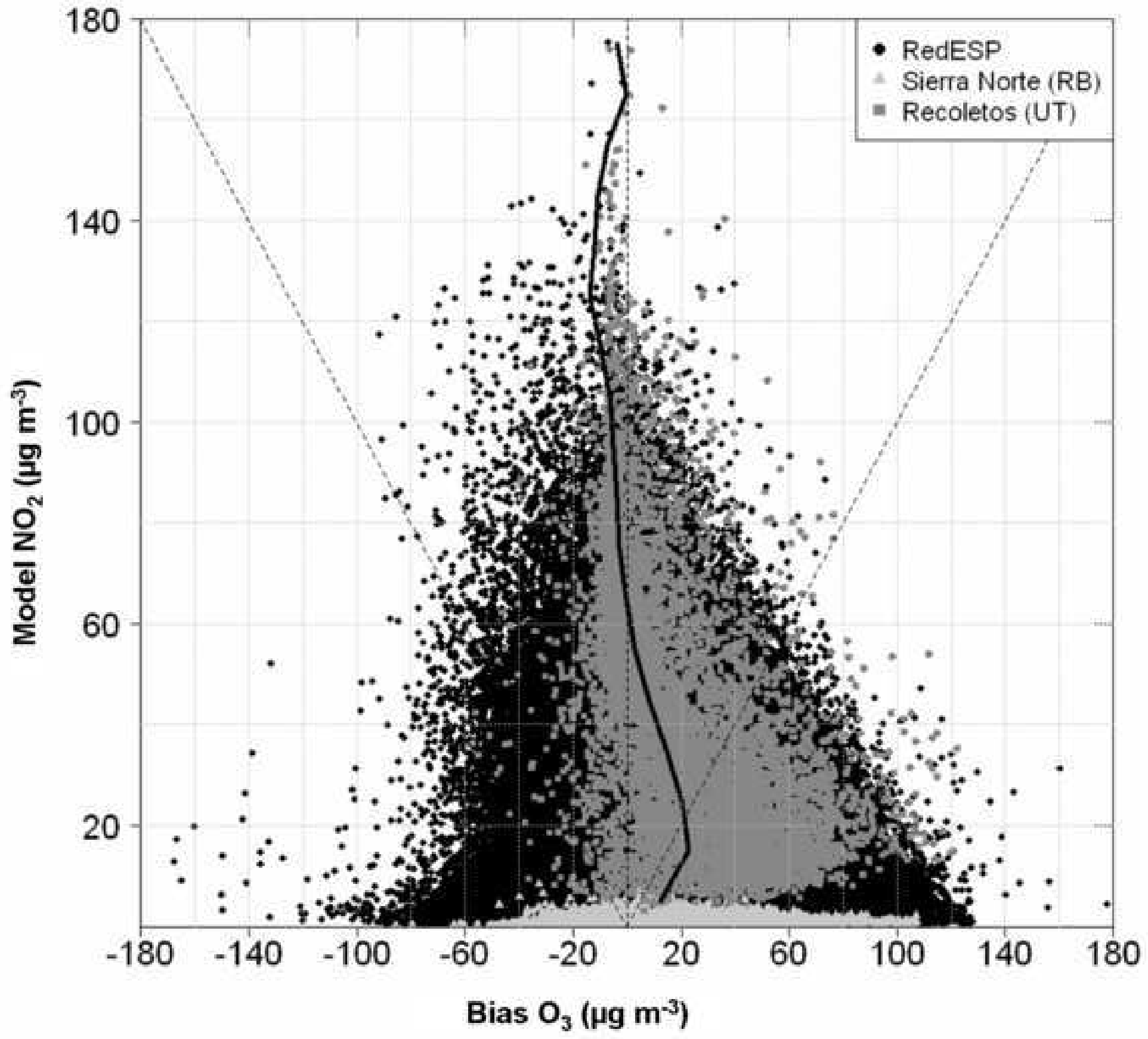




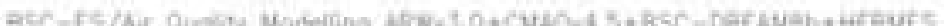

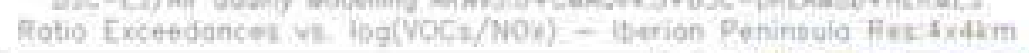

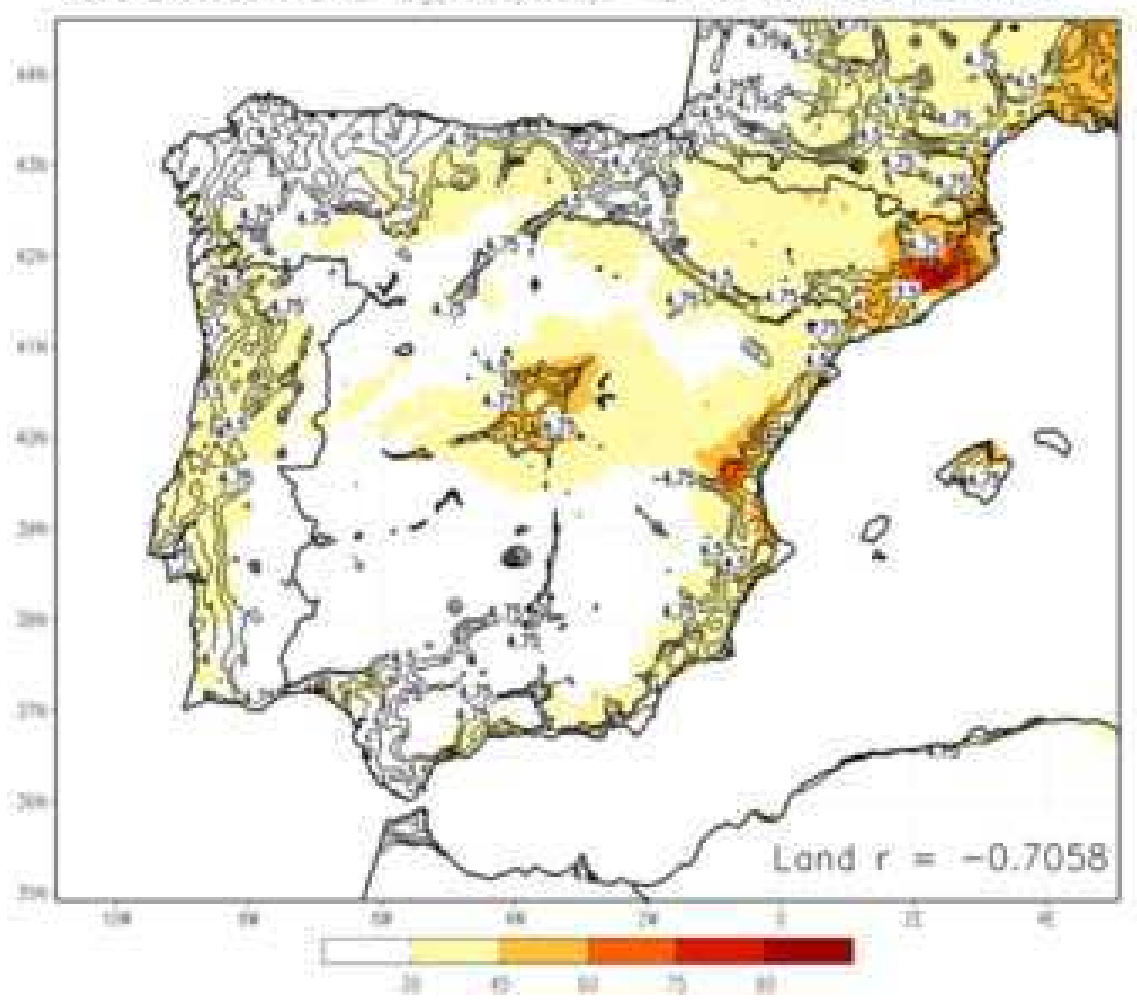

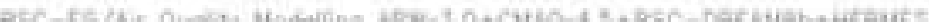

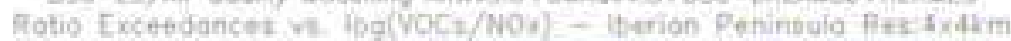

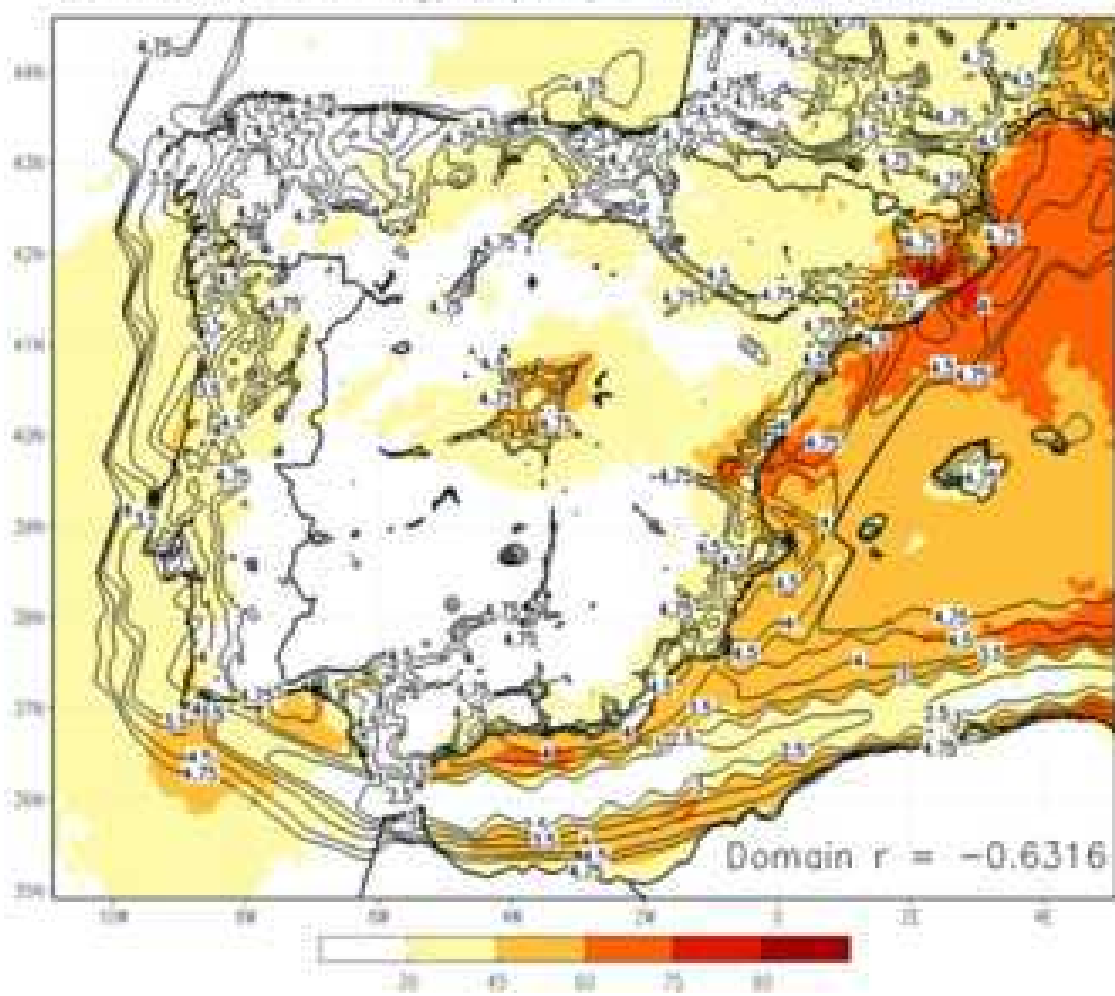

